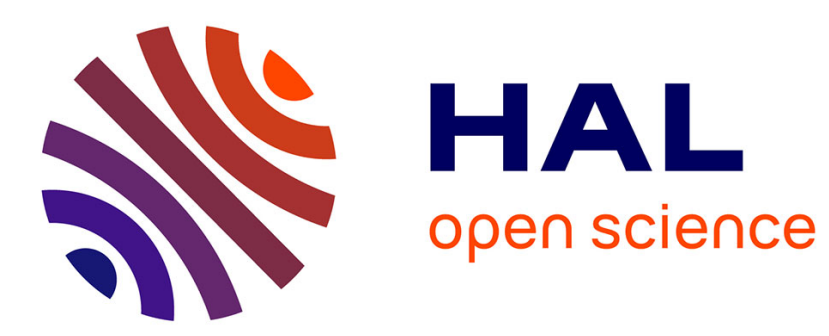

\title{
Evaluation of geochemical reactivity of hydrogen in sandstone: Application to geological storage
}

\author{
Alireza E. Yekta, Michel Pichavant, Pascal Audigane
}

\section{To cite this version:}

Alireza E. Yekta, Michel Pichavant, Pascal Audigane. Evaluation of geochemical reactivity of hydrogen in sandstone: Application to geological storage. Applied Geochemistry, 2018, 95, pp.182-194. 10.1016/j.apgeochem.2018.05.021 . insu-01803009

\section{HAL Id: insu-01803009 https://hal-insu.archives-ouvertes.fr/insu-01803009}

Submitted on 30 May 2018

HAL is a multi-disciplinary open access archive for the deposit and dissemination of scientific research documents, whether they are published or not. The documents may come from teaching and research institutions in France or abroad, or from public or private research centers.
L'archive ouverte pluridisciplinaire $\mathbf{H A L}$, est destinée au dépôt et à la diffusion de documents scientifiques de niveau recherche, publiés ou non, émanant des établissements d'enseignement et de recherche français ou étrangers, des laboratoires publics ou privés. 


\section{Accepted Manuscript}

Evaluation of geochemical reactivity of hydrogen in sandstone: Application to geological storage

A. E.Yekta, M. Pichavant, P. Audigane

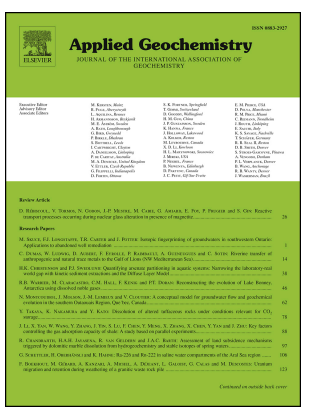

PII:

S0883-2927(18)30143-4

DOI:

10.1016/j.apgeochem.2018.05.021

Reference: $\quad$ AG 4098

To appear in: $\quad$ Applied Geochemistry

Received Date: 18 December 2017

Revised Date: 20 May 2018

Accepted Date: 25 May 2018

Please cite this article as: E.Yekta, A., Pichavant, M., Audigane, P., Evaluation of geochemical reactivity of hydrogen in sandstone: Application to geological storage, Applied Geochemistry (2018), doi: 10.1016/ j.apgeochem.2018.05.021.

This is a PDF file of an unedited manuscript that has been accepted for publication. As a service to our customers we are providing this early version of the manuscript. The manuscript will undergo copyediting, typesetting, and review of the resulting proof before it is published in its final form. Please note that during the production process errors may be discovered which could affect the content, and all legal disclaimers that apply to the journal pertain. 


\title{
Evaluation of geochemical reactivity of hydrogen in sandstone: application to geological storage
}

\author{
E.Yekta, A. ${ }^{(1)}$, Pichavant, M. ${ }^{(1)}$, Audigane, P. ${ }^{(2)}$ \\ ${ }^{(1)}$ ISTO : Institut des Sciences de la Terre d'Orléans, 1A Rue de la Ferollerie, 45100 Orléans, France \\ (2) BRGM Bureau de Recherches Géologiques et Minières, 3 Avenue Claude Guillemin, 45060 Orléans, France
}

\begin{abstract}
The use of hydrogen as an alternative for electric energy storage has emerged recently. Being composed of small molecules, hydrogen has a strong ability to migrate in porous medium and can also be highly reactive with rock-forming minerals. In the case of storage in sedimentary rocks such as sandstone, mineralogical transformations due to the presence of hydrogen may modify the porous structure of the rock and affect the storage properties. In this study, the geochemical reactivity of hydrogen with sandstone was assessed both experimentally and numerically. Experiments were performed to test the possibility of mineral transformations due to hydrogen, either pure or in presence of water. The experiments were carried out mostly at 100 and more rarely at $200{ }^{\circ} \mathrm{C}$. Maximum hydrogen pressures of 100 bar were imposed and experimental durations ranged from 1.5 to 6 months. The experimental products bear the mark of only very limited reaction between minerals in sandstone and hydrogen. Taken together with the numerical results, this study demonstrates that hydrogen, once injected, can be considered as relatively inert. Overall, our results support the feasibility of hydrogen confinement in geological reservoirs such as sandstones.
\end{abstract}

Keywords: Geochemical reaction, Abiotic reaction, Underground hydrogen storage, experimental study;

\section{Introduction}

The world's population will grow by 2 billion people by 2040 and we will need a lot more energy to meet demand. However, the most important energy source for the future is not fossil fuel so we have to move from fossil energy to renewable energy. Solar energy, wind power and moving water are all traditional sources of alternative energy that are making progress but these renewable energies have a weakness: their production is highly dependent on unpredictable climate conditions which may not fit in with population needs (Schaber et al., 2012).

The objective to integrate renewable energy in the global market induces the need to develop storage technologies to obtain alternative availability for later use when electricity demand is surpassing electricity generation. Therefore, renewable energy requires storage to maintain the energy balance between production and consumption.

Hydrogen, having a high availability and being clean, has long been discussed as a candidate for largescale energy storage for renewable energy systems (Foh et al., 1979; Carden and Paterson, 1979; Li, 2005; Crotogino et al., 2010; Ozarslan et al., 2012; HyUnder 2013; Lord et al., 2014). By way of electrolysis, it becomes one of the major actors in the possible conversion of wind power or solar energy. Favorable arguments include the high storage densities and the low environmental costs. Therefore, hydrogen can be an energy carrier for large scale use. However, this would require large volumes since hydrogen is gaseous. One solution would be to store hydrogen in subsurface geological formations, and in a way that would make it available depending on the customer's needs. 
The current technology for underground storage of hydrogen uses the same types of reservoirs as for natural gas. Depleted gas fields, aquifers or salt caverns are considered as possible storage sites (Bai et al., 2014). Although gas storage is a key step in the hydrogen economy (Crotogino et al., 2010), the loss of hydrogen through chemical reactions with confining rocks is one of the major geochemical and operational challenges (Bourgeois et al., 1979; Carden and Paterson, 1979; Foh et al., 1979; Lord, 2009). Truche et al. (2013) presented experimental evidence for precipitation of pyrrhotite due to reduction of pyrite present in the confining rock sample. These observations and results provide clear illustrations of the mode of action of hydrogen.

Because it is composed of small and light molecules, gaseous hydrogen has a strong ability to migrate in porous media and could be highly reactive with rock forming minerals. In fact, redox reactions induced by hydrogen can change the rock mineral assemblage and modify mineral dissolution and precipitation (Ganzer et al., 2013; Truche et al., 2013). The physical properties of the confining rocks, notably porosity and permeability, would be affected by these mineralogical transformations. In the case of hydrogen storage in sedimentary rocks, changes of the porous structure of the rock are expected and these might influence the capacity for underground gas storage.

Besides abiotic reactions, microbial activity under conditions of underground storage is the main cause of hydrogen consumption (Hagemann et al. 2015). It can affect the geochemical environment of gas storage and lead to significant loss of hydrogen (Reitenbach et al., 2015). Bacteria consume the energy produced from redox reactions involving hydrogen and other components in the reservoir; hydrogen is not consumed directly (Panfilov 2016). However, these microbial reactions were not considered in this study which is concerned only with abiotic reactions.

Mechanisms and kinetics of redox reactions induced by hydrogen in sedimentary rocks are yet poorly documented. Nevertheless, this is a topic of growing interest for underground hydrogen geological storage but also for nuclear waste storage assessment. The feasibility of hydrogen storage in porous geological formations has been discussed notably by Ganzer et al., (2013), Decourt et al., (2014) and Panfilov (2016). Temperatures of underground hydrogen storage are expected to range between $50^{\circ} \mathrm{C}$ and $100^{\circ} \mathrm{C}$ and the maximum hydrogen pressure is expected to be in the 100 bar range.

In the context of deep geological disposal of nuclear waste in a clay-rich host rock, Truche et al. (2010) presented an experimental kinetic study of mineralogical reactions induced by elevated hydrogen partial pressures ranging from 3 to 30 bar at low to medium temperatures $\left(90-180^{\circ} \mathrm{C}\right)$. $\mathrm{He}$ showed that, under the influence of hydrogen and for slightly alkaline conditions, pyrite is partially reduced to pyrrhotite, releasing sulfide anions in the solution. Hydrogen had a major impact on sulphur chemistry, but no significant effect was found on the other minerals present in the natural rock (clay minerals, quartz, calcite, dolomite and feldspars), even for a $\mathrm{P}_{\mathrm{H} 2}$ of 30 bar and a temperature of $150^{\circ} \mathrm{C}$ (Truche et al., 2013). The $\mathrm{pH}$ of the fluid medium was identified as a critical parameter controlling the extent of the reaction as alkaline conditions promoted pyrrhotite precipitation at lower temperatures and hydrogen pressures.

In the context of deep geological disposal of nuclear waste, the influence of hydrogen gas emissions on clays from the Callovo-Oxfordian (COx) was studied by Didier et al. (2012). Hydrogen was found to decrease structural $\mathrm{Fe}$ (III) in clays although in small proportions, and reduction was difficult at temperatures lower than $350^{\circ} \mathrm{C}$. At $90^{\circ} \mathrm{C}$ and low (less than 1 bar) $\mathrm{H}_{2}(\mathrm{~g})$ partial pressure, the natural clays were demonstrated to be stable.

The experimental study presented in this paper aims at evaluating the mineralogical impact of hydrogen on a sandstone lithology under conditions of natural hydrogen storage. To test the reactivity of the hydrogen/sandstone system, two distinct temperature ranges were chosen. A majority of experiments was performed at $100{ }^{\circ} \mathrm{C}$, which is close to the maximum temperature range expected for 
underground hydrogen storage. Additional experiments were performed at a higher temperature $\left(200^{\circ} \mathrm{C}\right)$ in order to: i) enhance reaction rates and ii) facilitate the identification of mineralogical transformations. The mineralogical changes were monitored by the analysis of experimental products with scanning electron microscopy (SEM), X-ray diffraction (XRD) and electron microprobe (EMP). In addition, numerical runs were performed with the PHREEQC (Parkhurst and Appelo, 1999) reactive transport code, mainly to extend the experimental observations to longer timescales. Results from this study emphasize the very limited reactivity of sandstones with respect to hydrogen gas. They document that hydrogen, once injected, can be considered as relatively inert and establish the feasibility of hydrogen confinement in geological reservoirs such as sandstones.

\section{Materials and methods}

\subsection{Geological context}

This study is directed at the testing of sandstone lithologies for underground hydrogen storage. To do so, lower Triassic sandstones (Buntsandstein formation) from the Vosges (France) were selected as test samples. These sandstones are representative of western European sandstone lithologies. They outcrop in a large geographical area and are now receiving increasing attention for geothermal applications (Aquilina et al. 2010, Blaise et al. 2016) as well as for $\mathrm{CO}_{2}$ storage (Le Gallo et al., 2010; Bader et al., 2014). Three sandstone samples were collected respectively from the Rotbach, Adamswiller and Cleebourg quarries.

\subsection{Samples and analytical methods}

Parts of each sample were crushed and sieved to grain sizes between 30 and $50 \mu \mathrm{m}$. The powders were analyzed by XRD and used as starting materials for the experiments. Sandstone thin sections were prepared and, in parallel, cores (5 $\mathrm{mm}$ diameter and $40 \mathrm{~mm}$ length) were drilled. These were used for the determination of rock physical properties and as starting materials for the experiments. Thin sections were also made from the cores recovered after the experiments.

Physical properties. Absolute permeabilities, pore volumes, porosities and densities were measured on cores drilled in the starting samples. The absolute permeability was obtained by the water coreflooding method using Darcy's law, as detailed in Yekta et al. (2018). Pore volumes were determined by mercury intrusion porosimetry using a Micromeritics Autopore IV 9500 instrument working from vacuum to $200 \mathrm{MPa}$. The intrusion and extrusion curves were obtained with an equilibration time of $60 \mathrm{~s}$ from low to high pressure. The porosity was obtained from the total volume (determined from the size of the core samples) and using the pore volume from above. The density was measured by weighing the samples in air and in water.

Optical microscopy. The thin sections (sandstones and experimental cores) were examined with a Zeiss petrographic microscope. Modal proportions of mineral phases in starting samples were determined with an automated Peltron point counter coupled with a petrographic microscope.

$X$-ray diffraction (XRD). The X-ray diffraction (XRD) data were obtained with an INEL diffractometer equiped with a curved position-sensitive detector. Sample powders were loaded in a glass capillary (Hilgenberg $\mathrm{GmbH} \mathrm{n}^{\circ} 50$ ). A $\mathrm{Cu}$ anode was used and the $\mathrm{Co} \mathrm{K} \alpha 1 \mathrm{X}$-ray line was selected using a bent quartz crystal monochromator. The scan parameters used were $0-90^{\circ} 2 \theta$, with a step size of $0.02^{\circ} 2 \theta$. Both starting and experimentally reacted samples were analyzed, the latter including powders and cores which were analyzed after gentle crushing. To facilitate the detection of mineralogical transformations, XRD results on experimental samples were compared against a reference.

Scanning electron microscopy (SEM). The thin sections (sandstones and experimental cores) were carbon-coated and mineral textures examined with a TESCAN MIRA 3 XMU instrument from the 
ISTO-BRGM analytical platform at Orléans. Energy-dispersive spectroscopy (EDS) analyses of specific grains were also performed for mineral identification and element distribution maps acquired to assist mineral identification.

Electron microprobe (EMPA). Mineral phases in thin sections (sandstones and experimental cores) were analyzed with the Cameca SX Five instrument of the ISTO-BRGM analytical platform at Orléans. The microprobe was operated at $15 \mathrm{kV}$ acceleration voltage and $6 \mathrm{nA}$ sample current. Natural mineral standards were used. Counting times were $10 \mathrm{~s}$ on peak and $5 \mathrm{~s}$ on background, and a focused beam was used.

Numerical modeling. In parallel with the experiments, geochemical modeling of fluid-rock interactions was performed with the PHREEQC geochemical software V.3.1.5 (Parkhurst and Appelo, 1999). The simulations were carried out to test the influence of hydrogen on sandstone in presence of water only (compare with experimental study that performed in presence of water (no. 8, Table 3)). They provide a theoretical reference frame to predict the appearance of mineral product phases and enable timescales to be extended beyond the experimental range. The calculations were performed both in equilibrium and kinetic modes (e.g., Pudlo et al., 2013).

\subsection{Experimental methods}

Static batch reactor experiments were conducted to evaluate the effect of gaseous hydrogen on sandstone at pressures and temperatures representative of reservoir conditions. In these experiments, duration was taken as the main experimental parameter.

Experimental charges. Both cores and powders were experimentally tested and results with these two rock types are combined below. The starting materials ( $1.5 \mathrm{~g}$ for each charge) were dried in an oven at $120^{\circ} \mathrm{C}$ for $20 \mathrm{~min}$ and then loaded in Au capsules of $50 \mathrm{~mm}$ length. In one experiment, the core was saturated with water before being loaded in the capsule. In most cases, capsules were fitted with a porous ceramic plug at both ends (Figure 1a). This procedure enabled gas from the pressure medium (either $\mathrm{H}_{2}$ or Ar) to access freely to the sandstone during the experiment while preserving the charge from being in contact with the autoclave walls. It also ensured the confinement of the charge for experiments performed with powders.

In one experiment designed to test the effect of hydrogen on sandstone in presence of water, a different charge assembly was used (Figure $1 \mathrm{~b}$ ). The charge ( $1.4 \mathrm{~g}$ of sandstone plus $150 \mathrm{mg}$ of $\mathrm{H}_{2} \mathrm{O}$, water/rock ratio of $\sim 0.1$ ) was loaded in the Au capsule together with pure Fe powder, and the capsule was hermetically closed at both ends by welding. Hydrogen was generated from inside the capsule by allowing the water present to react with the Fe powder. The sandstone inside the capsule was thus allowed to react with a $\mathrm{H}_{2} \mathrm{O}-\mathrm{H}_{2}$ fluid mixture. To prevent contamination with $\mathrm{Fe}$, the sandstone was physically separated from the Fe powder by a porous ceramic plug.

Experimental equipment and procedures. Capsules with experimental charges were placed inside a rapid-quench hydrothermal pressure vessel made of a Ni-rich alloy and working horizontally (Pichavant, 1987). After being closed, the vessel was pressurized to a total pressure of 100 bar and then inserted into the furnace. In most cases, the pressurizing gas was pure hydrogen. In two cases (synthesis of the XRD reference and $\mathrm{H}_{2} \mathrm{O}-\mathrm{H}_{2}$ fluid mixture experiment), Ar was used instead of hydrogen. It is worth mentioning that the pressure vessel initially contained air at atmospheric pressure. However, the number of moles of oxygen inside the vessel is negligible compared to the number of moles of hydrogen at a pressure of 100 bar. In addition, and although there may be kinetic limitations depending on experimental temperature, oxygen would readily react with hydrogen to form water during the experiments. Therefore, most oxygen initially present should be chemically consumed during the experiments. 
During the experiment, temperature was monitored with an Eurotherm regulator and permanently recorded with a thermocouple inserted in the autoclave wall. Pressure was measured with a manometer (pressure range: $0-500$ bar; measurement error $<1 \%$ of full scale value) and adjusted during the course of the experiment, if necessary. Uncertainties on temperature and pressure are $+/-10^{\circ} \mathrm{C}$ and $+/-$ 20 bar respectively. Once the experiment was completed, the pressure vessel was removed from the furnace, allowed to cool at room temperature $(<1$ hour) and opened. The capsules were recovered and the samples prepared for analysis.

\section{Results}

\subsection{Mineralogical and physical parameters of sandstones}

The mineral modes of the three studied sandstones are detailed in Table 1. Point counting results, plus XRD data, enable the mineralogical composition of the samples to be determined. Quartz and feldspar are the dominant minerals in the three rocks and, together, they account for 95-97\% of the total mineral proportion. With a modal amount of $74-80 \%$, quartz is the most abundant phase, followed by K-feldspar (17-26\%). Mica (muscovite according to the XRD results) is the main accessory mineral (0.6-2.3\%). An oxide phase (hematite according to the XRD results) and clay minerals (only distinguished from muscovite by microscopic examination) occur as minor phases (modal proportions 0.3-0.9 and 0.6-1.0 \%, respectively). Although phase proportions can vary (Table 1), there is no change in mineral assemblage between the three studied samples. Because mica and oxide proportions are the highest in sample 1\# (Adamswiller quarry), this sandstone was selected for the experimental study.

The physical data for the three sandstones are reported in Table 2. Although some dispersion is apparent, permeabilities do not vary by more than a factor of 2 between samples. Porosities are in the $15-20 \%$ range and tightly grouped. The Rotbach sandstone has a high density compared to the two other samples.

\subsection{Experimental results}

General. Experimental conditions and results are summarized in Table 3. Durations ranged from 1.5 to 6 months. Five experiments were performed at $100^{\circ} \mathrm{C}$ and three at $200^{\circ} \mathrm{C}$. Experiment no. 3 is the one which started from a wet core, instead of a dry one as in all the other experiments. The experiment with the mixed $\mathrm{H}_{2} \mathrm{O}-\mathrm{H}_{2}$ fluid phase (no. 8, Table 3) was performed at a temperature of $100^{\circ} \mathrm{C}$ and a pressure of 100 bar, and the partial pressure of hydrogen in the $\mathrm{H}_{2} \mathrm{O}-\mathrm{H}_{2}$ fluid mixture is estimated to be in the 10-50 bar range. The reference charge for the XRD data was synthesized in experiment no. 1. A blank test was performed for the $\mathrm{H}_{2} \mathrm{O}$-free experiments which are the most numerous. We emphasize that the $\mathrm{H}_{2} \mathrm{O}$-bearing experiment is a preliminary one. However, as detailed below, the results from that experiment show no major difference with the other experiments performed without water.

Textural evolution. Textures of starting materials and representative experimental products are summarized in Figure 2. Observations by optical microscopy and SEM yielded similar results. SEM microphotographs of experimental charges for "dry" conditions as well as for the "wet" experiment are illustrated. Overall, no clear textural change appears between samples, whether coming from the starting materials or from experimentally reacted charges. Quartz and feldspar minerals form grains with sizes mostly in the 100-200 $\mu \mathrm{m}$ range and they show typical anhedral rounded morphologies. No difference can be noted between experimental samples, whether "dry" or "wet" (Figure 2a; d; g). Muscovite appears as sub-euhedral flakes, 50 to $200 \mu \mathrm{m}$ in size, and no apparent textural modification emerges between the three different types of samples, starting material, experimental "dry" and experimental "wet" (Figure 2b; e; h). Fe oxides were found to occur under more variable habits in the 
sandstones, from small crystals included in quartz or feldspar minerals (Figure 2c; f) to interstitial grains, sometimes large $(50 \mu \mathrm{m})$ in size (Figure 2i). However, they show no textural indication for a mineralogical transformation, even partial or local. Therefore, the optical and SEM examinations reveal no significant textural changes in experimental products in comparison with the starting sandstones. This is true both for experimental samples reacted with and without $\mathrm{H}_{2} \mathrm{O}$ (Figure $2 \mathrm{~g} ; \mathrm{h} ; \mathrm{i}$ ) and at 100 and at $200^{\circ} \mathrm{C}$ (Figure 2f).

Phase assemblages and structural evolution. The XRD results are summarized on Table 4. They show that the same phase assemblage (quartz, feldspar, muscovite, hematite) is present in the samples before and after the experiments. Magnetite was looked for but never positively identified. Clay minerals were not positively detected although a weak peak indicative of kaolinite might be present in some samples. Therefore, reacting the sandstone with hydrogen caused no first-order modification in the phase assemblage from the starting rock.

The XRD signatures of quartz and feldspars did not change before and after the experiments. However, differences were noted between the reference and the experimental samples concerning muscovite (Table 3). Most sandstones annealed under hydrogen showed an increase of muscovite XRD peak intensities compared to the reference, as illustrated in Figure 3. The most marked intensity increases were noted for charges no. 4, 5, 6 and 7, i.e., for two "dry" $200^{\circ} \mathrm{C}, 3$ month $(4,5)$ and two "dry" $100^{\circ} \mathrm{C}, 6$ month $(6,7)$ experiments. In comparison, the "wet" charge (no. 8, 1.5 month, Table 3) did not show much variation compared to the reference, and the two 1.5 month experiments (no. 2, 3) were relatively little modified (Figure 3). Although overall these changes are of minor importance, they are considered as significant since they occur in several charges. They indicate that some mineralogical transformations, such as muscovite recrystallization or growth, took place during the experiments.

Additional evidence for mineral reaction during the experiments is provided by the Fe oxides. In our experimental charges, the only $\mathrm{Fe}$ oxide identified by XRD is hematite and magnetite was never found. Contrary to an expected reduction of hematite under the influence of hydrogen, the XRD peaks diagnostic hematite showed intensity increases in several charges, in particular in experiments 6 and 7 (Figure 4). Again, in the "wet" no. 8 charge, hematite peaks showed little intensity changes relative to the reference (Figure 4). Therefore, and although detailed information is lacking to interpret these changes, the XRD signature of Fe oxides further demonstrates that limited but detectable mineral reaction takes place in the experiments as a result of hydrogen.

Compositional evolution. Results of electron microprobe analyses of minerals before and after the annealing experiments under hydrogen are summarized on Table 5. Three phases in particular were investigated, K-feldspar, muscovite and hematite and, for each, electron microprobe data before and after the experiments are given. Average values and standard deviations are provided especially for muscovite whereas, for the other phases, only starting compositions have been averaged because of more limited data. The generally low standard deviations (e.g., $<0.5 \mathrm{wt} \%$ for $\mathrm{SiO}_{2}$ in $\mathrm{K}$-feldspar, $\mathrm{FeO}$ in muscovite and $\mathrm{TiO}_{2}$ in hematite) indicate that mineral phases in the starting sandstone are subhomogeneous. K-feldspar is nearly pure, containing very little $\mathrm{Na}_{2} \mathrm{O}$ (on average $0.37 \mathrm{wt} \%$ ) and very low (below detection) $\mathrm{FeO}_{\mathrm{t}}$. Muscovite contains significant amounts of $\mathrm{FeO}_{\mathrm{t}}$ (on average $3.54 \mathrm{wt} \%$ ), $\mathrm{MgO}(1.20 \mathrm{wt} \%), \mathrm{TiO}_{2}(0.78 \mathrm{wt} \%)$ and $\mathrm{Na}_{2} \mathrm{O}(0.44 \mathrm{wt} \%)$. Hematite has low $\mathrm{Al}_{2} \mathrm{O}_{3}$ (on average 0.48 wt $\%), \mathrm{MnO}(0.22 \mathrm{wt} \%)$ and $\mathrm{MgO}(0.02 \mathrm{wt} \%)$ but relatively high $\mathrm{TiO}_{2}(9.12 \mathrm{wt} \%)$, which corresponds to a solid solution between ilmenite and hematite in a 0.18:0.82 proportion (mole fraction). Experimentally reacted K-feldspars and hematites are chemically homogeneous and they show little compositional differences with minerals in the starting sandstone. One K-feldspar analysis (no. 5) is exceptionally $\mathrm{Na}_{2} \mathrm{O}$-rich $(1.38 \mathrm{wt} \%)$. The range of $\mathrm{TiO}_{2}$ concentrations in experimental hematites 
(9.01 to 10.2) encloses the average in the starting sample. In contrast, experimental muscovites record a minor but detectable compositional change from the starting sandstone. $\mathrm{FeO}_{\mathrm{t}}$ concentrations decrease from $~ 3.5 \mathrm{wt} \%$ before experiments to values ranging from 1.24 to $2.48 \mathrm{wt} \%$ in experimental samples. Charges no. 3 and 8 (respectively performed with a wet starting core and a $\mathrm{H}_{2} \mathrm{O}-\mathrm{H}_{2}$ fluid, Table 3) show the maximum deviations, whereas muscovites in charges no. 5 and 7 (two "dry" charges at 200 and $100^{\circ} \mathrm{C}$, Table 3) appear less chemically modified. Apart from $\mathrm{FeO}_{\mathrm{t}}$ concentrations, the other oxides show no significant changes when compared with the starting composition and, so, the chemical modifications recorded by muscovite are relatively minor. However, they demonstrate that mineral phases can change their compositions during the experiments as a result of interaction with hydrogen.

\subsection{Geochemical simulations}

The geochemical simulations were performed without any transport, i.e., the fluid phase is static and every single chemical component is homogeneously distributed (1D batch experiment). This type of modeling is analogous to experiments performed in this study, i.e., no chemical transport is involved. Two approaches were considered in the simulations: equilibrium and kinetic.

Equilibrium mode was considered to check the stability of mineral phases initially present in sandstone and to identify mineral reaction products. In this approach, thermodynamic equilibrium is assumed between hydrogen, water and sandstone minerals. Information is thus provided on the reference equilibrium state of the fluid-rock system. This approach is useful to predict the nature of equilibrium mineral phases during interaction between sandstone and hydrogen in presence of water. It enables to identify which phase from the sandstone remains stable and which becomes unstable.

In order to analyze the rates of mineralogical transformations, the geochemical simulations were also performed in kinetic mode (Appendix A). This approach is directly analogous to the experiments performed in this study. However, contrary to most experiments that were run under dry conditions (Table 3), the simulations were carried out in presence of an aqueous fluid phase. Therefore, strictly speaking, the modeling only matches / extends the non-dry experiment (no. 8, Table 3 ).

Experimental results from this study have not revealed first-order modifications in phase assemblage such as phase appearance or disappearance. Therefore, no experimental constraint on mineral reaction rates in presence of hydrogen is available. Yet, the kinetic expression given by Lasaga et al. (1994) was used to predict reaction rates with kinetic parameters for the minerals taken from Palandri and Kharaka (2004) (Appendix A).

Parametrization. 100 moles of sandstone rock from Adamswiller were reacted with pure water in presence of $\mathrm{H}_{2}$ gas. The simulations were performed at $100^{\circ} \mathrm{C}$, and for a $\mathrm{H}_{2}$ pressure set at 100 bar in most cases, and more rarely at 10 bar. Three water/rock mass ratios (W/R) were tested, 0.1 (as in the experiments (no. 8, Table 3)), 1 and 10, to reproduce long time-integrated fluid circulations. As an initial step, calculations in equilibrium mode guided the choice of mineral product phases to be considered since, in the experiments, phase assemblages did not vary and no product phase was identified. Then, simulations in kinetic mode were performed in two cases, the first without mineral product phases (and so simulating the simple dissolution of sandstone minerals in the fluid, the mineralogical composition being set constant as in Table 1) and the second with selected product mineral phases included (coupled mineral dissolution and precipitation).

Equilibrium results. When in equilibrium mode, a number of phases appeared as possible products of the interaction between sandstone and hydrogen in presence of water. These product phases did not change significantly with varying input parameters such as the $\mathrm{H}_{2}$ pressure which was reduced from 100 to 10 bar in a few runs. They include: magnetite $\left(\mathrm{Fe}_{3} \mathrm{O}_{4}\right), \mathrm{Fe}$-mica (annite), Fe-chlorite (chamosite), Fe-serpentine (cronstedtite), fayalite $\left(\mathrm{Fe}_{2} \mathrm{SiO}_{4}\right)$, wustite $(\mathrm{FeO})$, ferrosilite $\left(\mathrm{FeSiO}_{3}\right)$, 
greenalite, minnesotaite and nontronite (Table 6). The highest computed saturation indexes were found for annite, chamosite and minnesotaite. These equilibrium calculations predict phase assemblages expected to be present at equilibrium upon transformation of sandstone by hydrogen. They stress the presence of various hydrous $\mathrm{Fe}$ silicates (annite, chamosite, cronstedtite, greenalite, minnesotaite, nontronite) and the reduction of $\mathrm{Fe}$ from $\mathrm{Fe}^{3+}$ in mainly hematite to $\mathrm{Fe}^{2+}$ in magnetite, fayalite, wustite and ferrosilite. It is important to emphasize that quartz and $\mathrm{K}$-feldspar remain stable during the interaction. Therefore, the mineral changes above concern phases such as muscovite, hematite and clay minerals which overall form a minor volumetric fraction in our sandstone.

Kinetic results. Results for simple dissolution are illustrated in Figure 5. Changes in mass fractions of mineral phases from the sandstone are plotted as a function of time for the $3 \mathrm{~W} / \mathrm{R}$ considered. The calculations assume constant specific surfaces of $10 \mathrm{~cm}^{2} / \mathrm{g}$ and $20 \mathrm{~cm}^{2} / \mathrm{g}$ for quartz and feldspar, and muscovite and hematite, respectively (Yekta et al. 2018). The influence of hydrogen on mineral dissolution can be appreciated from the curves calculated without hydrogen for $\mathrm{W} / \mathrm{R}=1$. Results show that, with and without hydrogen, the dissolution curves for quartz, K-feldspar and muscovite are identical but the dissolution of hematite becomes strongly affected. In presence of hydrogen, the 4 major minerals follow an initial decrease of their mass fraction, interpreted as mineral dissolution in the fluid. Then, plateau values are reached for each mineral phase, although these are attained after durations that depend on the mineral, and in particular on the W/R for a given mineral. These plateau values are interpreted to reflect saturation of the fluid with respect to the dissolving mineral phase. For quartz and hematite, plateau values are attained only for a W/R of 0.1, in both cases after 1-10 years. No saturation is observed after $10^{2}$ years for a W/R of 1 and 10 (Figure 5). In contrast, aluminous phases (K-feldspar and muscovite) reach saturation for the $3 \mathrm{~W} / \mathrm{R}$ considered. In both cases, saturation is attained after durations that increase monotonously with the W/R, from 0.1 to $<10$ years for $\mathrm{K}$ feldspar and from $<0.01$ to $<1$ years for muscovite.

Results for combined mineral dissolution and precipitation are illustrated by considering first magnetite as the only product phase. When compared with simple mineral dissolution (Figure 5), mass fractions for quartz, K-feldspar and muscovite show no variations and dissolution curves for the "with" and "without magnetite" cases perfectly overlap, irrespective of the W/R. For hematite, the introduction of magnetite leads to a decrease of its mass fraction when compared (for the same duration) with the "without magnetite" case (Figure 6). Therefore, the mass fraction of hematite decreases more rapidly when magnetite precipitates as a reaction product. The mass of magnetite progressively increases with time and curves for the production of magnetite are progressively shifted to longer durations when the $\mathrm{W} / \mathrm{R}$ is increased. For W/R $=0.1$, i.e., for conditions approaching the experiments, the calculations suggest that 100 years are necessary to produce $0.001 \mathrm{~g}$ of magnetite (mass normalized to $100 \mathrm{~g}$ of reactant rock).

In a second case, a multiphase product assemblage, including magnetite, annite and chamosite (Table 6) was considered. This complex assemblage leads to modifications of rates of dissolution of quartz and K-feldspar. Focusing on results for a W/R of 1, the quartz and K-feldspar dissolution curves are both shifted from those obtained when no product mineral is considered (Figure 7a). For quartz, the effect of the multiphase product assemblage becomes apparent only after long durations, higher than 10 years. Quartz dissolution is slightly faster when product minerals are included. In contrast, the dissolution of K-feldspar proceeds slightly more slowly in presence of the product assemblage. The difference between the two dissolution curves appears very early, for durations $<0.1$ year (Figure $7 \mathrm{a}$ ). Muscovite dissolution (not shown) is not affected. Masses of annite and chamosite increase progressively with time to reach values $>0.001 \mathrm{~g}$ (normalized to $100 \mathrm{~g}$ of reactant rock). No magnetite appears in product assemblages most probably because it is allowed to react to form annite. The 
chamosite production curve shows a complex evolution with time with a maximum mass attained after $\sim 50$ years (Figure $7 b$ ).

\section{Discussion}

\subsection{Mineralogical transformations of sandstone under the influence of hydrogen}

Laboratory experiments from this study have provided direct observations on the reaction of sandstone minerals in presence of hydrogen. Experimental conditions were adjusted to those considered typical for underground hydrogen storage, considering the Trias geological context in France at about $1500 \mathrm{~m}$ depth (hydrogen pressure $100 \mathrm{bar}$, temperature $100^{\circ} \mathrm{C}$, sometimes $200^{\circ} \mathrm{C}$ ). Some experiments lasted up to 6 months. It is worth emphasizing that most experiments were performed in the absence of water. Only one experiment has simulated the influence of hydrogen on sandstone in presence of water.

Overall, the experimental results indicate very limited modifications of sandstone minerals because of the presence of hydrogen. No significant textural changes were found in experimental products in comparison with the starting sandstones (Figure 2). The XRD data showed no major mineral transformation from the reference sample. However, limited but systematic mineralogical changes were noted on the XRD spectra for both muscovite and hematite. For muscovite, the most extensive modifications were found in the 3 and 6 month charges (Figure 3). No influence of the presence of water could be detected but the experiment performed in presence of water had a rather short duration (1.5 month). For hematite, the maximum changes were also found in the 6 month charges (Figure 4). Electron microprobe data revealed shifts in the composition of certain mineral phases as a result of interaction with hydrogen. Muscovite, with $\mathrm{FeO}_{\mathrm{t}}$ concentrations decreasing in experimental samples, is clearly chemically modified (comparable to the small reduction of $\mathrm{Fe}$ (III) in clays in presence of hydrogen, Didier et al., 2012). In comparison, neither hematite nor K-feldspar showed significant compositional variations (Table 5). Interestingly, the maximum chemical deviations in muscovite are associated with the "wet" samples, and not with the longest experimental charges. This suggests that the mineralogical transformations seen in the XRD data and those revealed by the mineral compositional data are decoupled.

Despite the limited mineralogical transformations identified in experimental products, the results undoubtly indicate that mineral reactions take place in sandstone during interaction with hydrogen. In this study, mechanisms of mineralogical transformations have not been clearly identified and this would probably require experiments of durations longer than 6 months (to promote the advancement of the reactions) as well as the implementation of analytical methods allowing mineral characterization at spatial resolutions $<1 \mu \mathrm{m}$. The geochemical modeling results confirm that mineralogical changes are expected in sandstones upon interaction with hydrogen. They demonstrate that the attainment of equilibrium in the sandstone-hydrogen system is accompanied by the appearance of new stable mineral phases (Table 6). Therefore, and despite the geochemical calculations being performed in presence of water only, both the experimental and theoretical approaches indicate that mineralogical changes should occur in the sandstone reservoir. However, we emphasize that all traces of mineral reaction found in the experiments concern muscovite and hematite. In the same way, the new phases identified from the geochemical calculations are Fe-bearing hydrous and anhydrous silicates and oxides. No changes have been found in experimental products for quartz and K-feldspar, and the equilibrium geochemical calculations show that both phases remain stable during the interaction (Table 6). Since quartz and K-feldspar are major mineral phases in sandstones, the sandstone microstructure is not expected to be significantly modified during interaction with hydrogen, even if minor phases such as muscovite or Fe oxide undergo mineral transformations. Therefore, the physical properties (porosity, permeability) that control the efficiency of sandstone as a reservoir will remain 
essentially unmodified. It is concluded that quartz- and K-feldspar-rich lithologies such as sandstone are highly stable with respect to interaction with hydrogen.

\subsection{Temporal evolution of sandstone reservoir in presence of hydrogen}

As discussed in section 4.1, our experimental conditions have been chosen to be representative of large-scale hydrogen injection regarding the Trias geology in France. Yet, in the experiments, no product phase was identified and mineral phase assemblages did not vary with time, despite rather long experimental durations, up to 6 months. The experiments thus bring no constraint on the temporal evolution of the sandstone reservoir in presence of hydrogen. In comparison, results of the geochemical simulations allow the durability of the sandstone reservoir to be explored over timescales that largely exceed the experimental range. Conditions chosen for the calculations (temperature of $100^{\circ} \mathrm{C}$, same mineralogical composition as the Adamswiller sandstone, presence of water, W/R, hydrogen pressure in the 10-100 bar range) overlap with the conditions in the experiments, although the latter have been mostly performed water-free. Therefore, the main differences between the experiments and the simulations concern time and W/R, extended to 100 years and to 1 and 10 respectively in the simulations.

Underground gas storage operations are usually performed using a cushion (inert) gas like nitrogen to prevent any leak out of the reservoir or any contact between the injected gas and ground waters of the reservoir formation. Nevertheless, after injection, some residual water is still present inside the pore structure of the rock and therefore fluid rock geochemical interactions require to be considered. This statement highlights the importance of evaluating the potential reactivity of hydrogen with native fluid and rocks of the reservoir at both dry and wet conditions.

Results of the simulations constrain the timescales of fluid-mineral interaction processes that take place in the reservoir. Saturation of the fluid with respect to the main sandstone minerals is attained for durations that depend on the mineral and W/R, but range from $<1$ to $>100$ years. Hydrogen has little effect on the dissolution kinetics of quartz, K-feldspar and muscovite, but it strongly influences (accelerates) hematite dissolution (Figure 5). Hematite dissolution in the fluid is also faster when magnetite is introduced as a product mineral (Figure 6). Magnetite reaches $0.1 \mathrm{mg}$ after durations of < 10 to $\approx 50$ years depending on the W/R, i.e., for timescales well beyond the experimental range. It is also worth emphasizing that the proportion of magnetite produced ( $100 \mathrm{~g}$ normalized mass $\approx 0.0011 \mathrm{~g}$ after 100 years for $\mathrm{W} / \mathrm{R}=0.1$, Figure 6a) would make its detection by XRD difficult. In other words, the masses of magnetite expected to be produced as a result of interaction between sandstone and hydrogen are not inconsistent with the fact that magnetite was not detected in the experimental products.

Magnetite production in the simulations could be accounted for by the Schikorr reaction:

$$
3 \mathrm{Fe}(\mathrm{OH})_{2} \rightarrow \mathrm{Fe}_{3} \mathrm{O}_{4}+\mathrm{H}_{2}+2 \mathrm{H}_{2} \mathrm{O}
$$

It describes the conversion of $\mathrm{Fe}$ hydroxide to magnetite and the associated hydrogen production. $\mathrm{Fe}$ hydroxide might be present as a mineral in sandstone. However, it was not positively identified (by X rays) in our samples which contain hematite instead of Fe hydroxide. Therefore, the following reaction:

$$
3 \mathrm{Fe}_{2} \mathrm{O}_{3}+\mathrm{H}_{2} \rightarrow 2 \mathrm{Fe}_{3} \mathrm{O}_{4}+\mathrm{H}_{2} \mathrm{O}
$$

is viewed as the most plausible mechanism to account for the simultaneous increase in magnetite and decrease in hematite proportions in the simulations (Figure 6). 
When more complex product assemblages are considered, the kinetics of quartz and K-feldspar dissolution become modified but saturation is attained in both cases after durations in the same range (from $<1$ to $>10$ years) as for simple mineral dissolution (Figure 7).

\section{Conclusions}

Hydrogen can be stored underground in several types of geological formation. Porous formations could potentially provide high storage capacity and impact of hydrogen on the rock formations should be considered, however, experiences with subsurface porous media hydrogen storage are relatively scarce. The redox reactions of minerals in rocks induced by hydrogen are yet poorly documented and just reduction of pyrite in contact with hydrogen has been presented in the work of Truche et al. (2013). He documented the reduction of pyrite into pyrrhotite under hydrogen partial pressures up to > $30 \mathrm{bar}$ and temperatures as high as $150^{\circ} \mathrm{C}$. Therefore, the same type of chemical modifications is expected in other minerals and rocks such as the one considered in this study.

In this study, we have performed the experimental and numerical study to evaluate the geochemical reactivity of hydrogen on the mineral components of Vosges sandstone lithology at the underground hydrogen storage. The experimental results demonstrated that mineralogical changes of Vosges sandstone in contact with hydrogen in reservoir conditions are minor. In fact, compared with starting rocks (before experiments), there are no variation concerning quartz and K-feldspars. There are just minor mineralogical changes concerning muscovite and hematite proportions (XRD) and muscovite composition (Electron microprobe analysis). However, details of chemical changes are as yet unknown. Our study demonstrates changes on muscovite when annealed under hydrogen. The chemical modifications recorded by muscovite are relatively minor but they demonstrate that silicate mineral phases can change compositions during the experiments as a result of interaction with hydrogen. Therefore, these experimental results clearly show that hydrogen has a minor effect on the minerals present in the Vosges sandstone.

In addition, 1D batch numerical simulation approach (Appendix A) without any migration of phases (gas and water) and components was performed to simulate the laboratory experiments that were carried out in this study with the same conditions of temperature, hydrogen partial pressure and waterrock ratio (experiments (no. 8, Table 3)). The geochemical modeling results illustrated that in the long term, hydrogen has no major effect on abundant minerals like quartz and $\mathrm{K}$-feldspars and therefore on the formations of Vosges sandstone and only a minor reduction of hematite could be consider after at least one year.

Overall, this study illustrated that hydrogen has not major effect on Vosges sandstone and the impact of hydrogen could be limited on the reduction of hematite at the long duration and release of Iron from muscovite that are not influence on the rock properties (porosity and permeability) and therefore the reservoir properties. As the consequence, this study confirms that storing hydrogen in the porous geological formation of Vosges sandstone because of the minor influence of hydrogen on the rock formation is feasible. However, this experimental study shows that abiotic reactions between hydrogen and rocks can be excluded from the consideration as insignificant to hydrogen storage. 


\section{Appendix A: Hydrogen-water-rock interaction numerical simulation}

The calculations were performed without any transport, i.e., the fluid phase is static and every single chemical component is homogeneously distributed (1D batch experiment). The simulations were carried out to test the influence of hydrogen on sandstone assuming that an aqueous fluid phase is always present (compare to experiment no. 8, Table 3). They provide a theoretical reference frame to predict mineralogical reactions in sandstone, the appearance of mineral product phases and to constrain the timescales of the mineralogical transformations.

PHREEQC modeling was used in two different ways. First, it was used to check the stability of mineral phases initially present in sandstone and to identify mineral reaction products. This was based on the use of saturation indices (Equation A1) which were calculated from PHREEQC:

$$
S I=\log \left(\frac{Q}{K_{e}}\right) \leftrightarrow\left\{\begin{array}{ll}
<0 \text { undersaturated }: & \text { dissolution } \\
=0 \text { saturated: } & \text { equilibrium } \\
>0 \text { oversaturated: } & \text { precipitation }
\end{array}\right\}
$$

where $Q$ is the corresponding ion activity product and $K_{e}$ is the equilibrium constant. These $S I$ served to identify mineral phases either at equilibrium with the fluid, undergoing dissolution or appearing as reaction products. In this approach, PHREEQC is used in "equilibrium mode", i.e., thermodynamic equilibrium is assumed between fluids and sandstone minerals. These calculations in equilibrium mode are useful to assess the stability of sandstone phases. They provide information applicable to the very long term but rates of mineralogical transformations are left unexplored.

Therefore, temporal constraints need to be involved, especially at low temperatures. In the case of geological hydrogen storage, the time required for reservoir minerals to react and transform (following hydrogen injection and if unstable with the fluid) is an important issue because this would affect the stability of the reservoir site. Therefore, second, PHREEQC was used in "kinetic mode" to analyze rates of mineralogical transformations.

Rate law kinetic parameters in PHREEQC are derived from Palandri and Kharaka (2004). The reaction rate depends on how much of the mineral is available, how fast the reaction is and how far it is from equilibrium (Gundogan et al., 2011). The kinetic rate of each reaction is calculated using the expression given by Lasaga et al. (1994):

$$
r=k S_{r}\left(1-\left(\frac{Q}{K_{e}}\right)^{\theta}\right)^{\eta} a_{H^{+}}^{n}
$$

where $r$ is the kinetic rate (positive values of $\mathrm{r}$ indicate dissolution, negative indicate precipitation); $k$ is the rate constant $\left(\mathrm{mol} / \mathrm{m}^{2} / \mathrm{s}\right)$, which is temperature dependent, $S_{r}$ is the specific reactive surface area $\left(\mathrm{m}^{2} / \mathrm{g}\right), a_{H^{+}}^{n}$ is the aqueous activity of $H^{+}$ion and $\mathrm{n}$ is the order of the reaction. The parameters $\theta$ and $\eta$ are two parameters that depend on the experimental data and they are usually set equal to one.

To calculate the kinetic rate constant $k$ in Equation A2, acid-base mechanisms must be taken into account. Therefore, a general form of kinetic rate which includes the three $k$ variables (Palandri and Kharaka, 2004) is:

$$
\begin{gathered}
r=S_{r}\left[k_{25}^{N} \exp \left(\frac{-E_{a, N}}{R T_{\alpha}}\right)+k_{25}^{H} \exp \left(\frac{-E_{a, H}}{R T_{\alpha}}\right) a_{H}^{n_{H}}+k_{25}^{O H} \exp \left(\frac{-E_{a, O H}}{R T_{\alpha}}\right) a_{H}^{n_{O H}}\right](1-S R) \\
\frac{1}{T_{\alpha}}=\frac{1}{T}-\frac{1}{298.15}
\end{gathered}
$$

where $k_{25}$ is the rate constant at $25^{\circ} \mathrm{C}, E_{a}$ is the apparent activation energy, $R$ is the gas constant, $T$ is the absolute temperature, $a^{H}$ is the $H^{+}$activity, $\mathrm{n}$ is the reaction order with respect to $\mathrm{H}^{+}$and $\mathrm{OH}$, and $S R$ is the saturation state given by: 


$$
S R=\exp \left(\frac{\Delta G_{r}}{R T}\right)
$$

where $\Delta G_{r}$ is the Gibbs free energy of the reaction.

The input data for the PHREEQC kinetic modeling are summarized in Table A1. Determining specific surface areas for multi-mineralic system is still being discussed (Mitiku et al., 2013). Most often, surface areas are calculated based on geometrical considerations, e.g., assuming an assemblage of truncated spheres (Sonnenthal and Spycher, 2001). The calculations assume constant specific surfaces of $10 \mathrm{~cm}^{2} / \mathrm{g}$ and $20 \mathrm{~cm}^{2} / \mathrm{g}$ for quartz and feldspar, and muscovite and hematite, respectively, which are the dominant minerals in the studies sandstones (Table A1).

The database llnl was used in simulation. Therefore, below phases were considered in this study:

- K-Feldspar

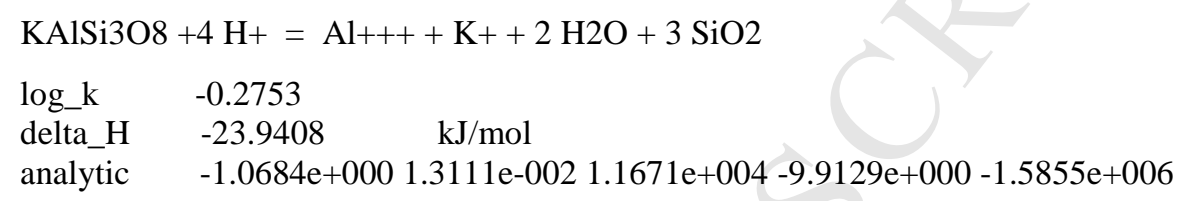

- Hematite

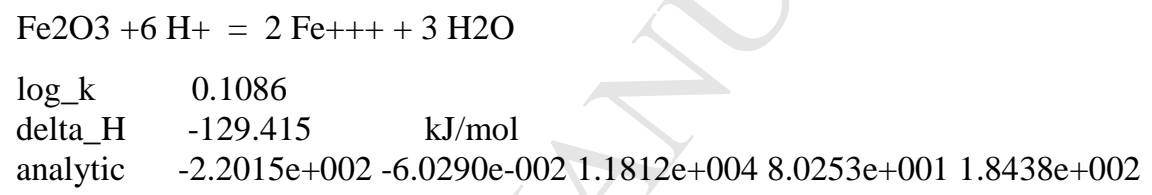

- Muscovite

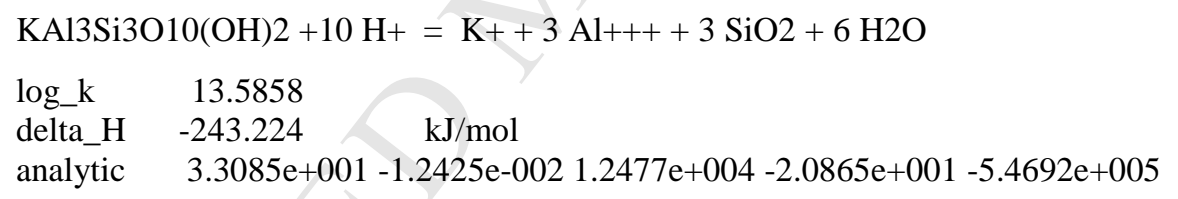

\section{Acknowledgements}

This research has been supported by ISTO (Institut des Sciences de la Terre d'Orléans), BRGM (Bureau de Recherches Géologiques et Minières) and university of Orleans. We would like to thank Catherine Lerouge and Joachim Trémosa from BRGM for helping in the collection of the samples at the quarries in the Vosges area and geochemical modeling and Remi Champallier from ISTO for helping to prepare the experiments instruments.

\section{Supplementary Materials}

Supplementary material associated with this article.

\section{REFERENCES}

Aquilina, L., Pauwels, H., Genter, A., \& Fouillac, C. (1997). Water-rock interaction processes in the Triassic sandstone and the granitic basement of the Rhine Graben: Geochemical investigation of a geothermal reservoir. Geochimica et cosmochimica acta, 61(20), 4281-4295.

Bader, A. G., Thibeau, S., Vincké, O., Jannaud, F. D., Saysset, S., Joffre, G. H., ... \& Copin, D. (2014). CO 2 Storage Capacity Evaluation in Deep Saline Aquifers for an Industrial Pilot Selection. Methodology and Results of the France Nord Project. Energy Procedia, 63, 2779-2788. 
Bai, M., Song, K., Song, K., Sun, Y., He, M., Li, Y., Sun, J., 2014. An overview of hydrogen underground storage technology and prospects in china. Journal of Petroleum Science and Engineering 124(2014)132136.

Blaise, T., Clauer, N., Cathelineau, M., Boiron, M. C., Techer, I., \& Boulvais, P. (2016). Reconstructing fluidflow events in Lower-Triassic sandstones of the eastern Paris Basin by elemental tracing and isotopic dating of nanometric illite crystals. Geochimica et Cosmochimica Acta, 176, 157-184.

Bourgeois, J.P., Aupaix, N., Bloise, R., Millet, J.L., 1979. Proposition d'explication de la formation d'hydrogène sulfuré dans les stockages souterrains de gas naturel par reduction des sulfures minéraux de la roche magasin. Revue de l'Institut Français du Pétrole 34, 371-386.

Carden, P.O., Paterson, L., 1979. Physical, chemical and energy aspects of underground hydrogen storage. International Journal of Hydrogen Energy 4, 559-569.

Crotogino, F., Donadei, S., Bünger, U., Landinger, H., Large-scale hydrogen underground storage for securing future energy supplies, Detlef Stotlen, Thomas Grube (Eds.): 18th World Hydrogen Energy Conference 2010 - WHEC 2010, Proceedings, May 16-21 2010, Essen. ISBN: 978-3-89336-654-5.

Decourt, B., Lajoie, B., Debarre, R., \& Soupa, O. (2014). The hydrogen-based energy conversion FactBook. The SBC Energy Institute.

Didier, M., Leone, L., Greneche, J.-M., Giffaut, E., Charlet, L., 2012. Adsorption of hydrogen gas and redox processes in clays. Environ. Sci. Technol. 46, 3574-3579.

Foh, S., Novil, M., Rockar, P., 1979. Underground Hydrogen Storage Final Report. Brookhaven National Laboratories, Upton, NY (268 pp.).

Ganzer L. V. Reitenbach, D. Pudlo, M. Panfilov, D. Albrecht, ,R. Gaupp, The H2STORE Project - Experimental and Numerical Simulation Approach to Investigate Processes in Underground Hydrogen Reservoir Storage Society of Petroleum Engineers, EAGE Annual Conference \& Exhibition incorporating SPE Europec, 10-13 June, London, UK Publication, 2013.

Gundogan, O., Mackay, E., \& Todd, A. (2011). Comparison of numerical codes for geochemical modelling of CO 2 storage in target sandstone reservoirs. Chemical Engineering Research and Design, 89(9), 1805-1816.

Hagemann, B., Rasoulzadeh, M., Panfilov, M., Ganzer, L., \& Reitenbach, V. (2015). Mathematical modeling of unstable transport in underground hydrogen storage. Environmental Earth Sciences, 73(11), 6891-6898.

HyUnder, (2013) D(4)- "Overview on all Known. Underground Storage Technologies for Hydrogen". Grant agreement no. 2/93. 14.08.2013. 303417.

Lasaga, A.C., Soler, J.M., Ganor, J., Burch, T.E., Nagy, K.L., 1994. Chemical weathering rate laws and global geochemical cycles. Geochim. Cosmochim. Acta 58, 2361- 2386.

Le Gallo Y., Fillacier, S., Lecomte A., Munier G., Hanot F., Quisel N., Rampnoux N., Thomas S., (2010), Technical challenges in characterization of future $\mathrm{CO} 2$ storage site in a deep saline aquifer in the Paris basin. Lessons learned from practical application of site selection methodology, Energy Procedia 4 (2011) 4599_ 4606.

Li, J., 2005. Underground gas storage in the Beijing-Tianjin region balanced the role of natural gas supply and demand .Int.Pet.Econ.13(6), 37-38.

Lord, A.S., 2009. Overview of Geologic Storage of Natural Gas with an Emphasis on Assessing the Feasibility of Storing Hydrogen. Sandia National Laboratories, Albuquerque, NM (SAND2009-5878, 28 pp.).

Ozarslan, A. (2012). Large-scale hydrogen energy storage in salt caverns. International Journal of Hydrogen Energy, 37(19), 14265-14277.

Palandri, J.L., Kharaka, Y.K., 2004. A compilation of rate parameters of water-mineral interaction kinetics for application to geochemical modeling. U.S.Geol. Surv. Open File Report 2004-1068.

Parkhurst, D. L., \& Appelo, C. A. J. (1999). User's guide to PHREEQC (Version 2): A computer program for speciation, batch-reaction, one-dimensional transport, and inverse geochemical calculations.

Panfilov, M. (2016). 4.1 Underground hydrogen storage as an element of energy cycle. Compendium of Hydrogen Energy: Hydrogen Storage, Distribution and Infrastructure, 91.

Pichavant, M. (1987). Effects of B and $\mathrm{H} 2 \mathrm{O}$ on liquidus phase relations in the haplogranite system at $1 \mathrm{kbar}$. American Mineralogist, 72, 1056-1070.

Pudlo, D., Ganzer, L., Henkel, S., Liebscher, A., Khn, M., Lucia, M., Panfilov, M., Pilz, P., Reitenbach, V., Albrecht, D., Wrdemann, H., Gaupp, R., 2013. Hydrogen underground storage in siliciclastic reservoirsintention and topics of the H2STORE project. In: EGU General Assembly Conference Abstracts, Geophysical Research Abstracts, v.15, EGU2013-4179-3.

Schaber, K., Steinke, F., Mühlich, P., \& Hamacher, T. (2012). Parametric study of variable renewable energy integration in Europe: Advantages and costs of transmission grid extensions. Energy Policy, 42, 498-508.

Truche, L., Berger, G., Destrigneville, C., Guillaume, D., Giffaut, E., 2010. Kinetics of pyrite to pyrrhotite reduction by hydrogen in calcite buffered solutions between 90 and $180{ }^{\circ} \mathrm{C}$ : implications for nuclear waste disposal. Geochimica et Cosmochimica Acta 74, 2894-2914. 
Truche, L., Jodin-Caumon, M. C., Lerouge, C., Berger, G., Mosser-Ruck, R., Giffaut, E., \& Michau, N. (2013). Sulphide mineral reactions in clay-rich rock induced by high hydrogen pressure. Application to disturbed or natural settings up to $250^{\circ} \mathrm{C}$ and 30bar. Chemical Geology, 351, 217-228.

Yekta, A. E., Manceau, J. C., Gaboreau, S., Pichavant, M., \& Audigane, P. (2018). Determination of HydrogenWater Relative Permeability and Capillary Pressure in Sandstone: Application to Underground Hydrogen Injection in Sedimentary Formations. Transport in Porous Media, 1-24. 
Table 1 Mineral modes of the studied sandstones

\begin{tabular}{llcccc}
\hline \multirow{2}{*}{$\begin{array}{l}\text { Sandstone } \\
\text { sample \# }\end{array}$} & \multicolumn{4}{l}{ Mineral types and content $($ Vol \%) } \\
\cline { 2 - 6 } & Quartz & K-feldspar & Mica & Oxide & Clay minerals \\
\hline 1 (Adamswiller) & 73.8 & 22.4 & 2.3 & 0.9 & 0.6 \\
2 (Cleebourg) & 71.6 & 25.7 & 1.4 & 0.3 & 1.0 \\
3 (Rotbach) & 80.9 & 17.2 & 0.6 & 0.5 & 0.8 \\
\hline${ }^{\mathrm{a} P o i n t ~ c o u n t i n g ~ o f ~ 500 ~ p o i n t s ~ p e r ~ t h i n ~ s e c t i o n . ~}$ & & &
\end{tabular}


Table 2 Physical parameters of the studied sandstones

\begin{tabular}{lccc}
\hline Parameters & Sandstone \#1 & Sandstone \#2 & Sandstone \#3 \\
\hline Permeability (mD) & 46 & 85 & 98 \\
Porosity $(\%)$ & 19.8 & 16.4 & 18.8 \\
Density $\left(\mathrm{g} . \mathrm{cm}^{-3}\right)$ & 1.96 & 1.85 & 2.31 \\
\hline
\end{tabular}


Table 3 Experimental conditions and results for sandstone \#1

\begin{tabular}{|c|c|c|c|c|c|c|c|c|c|c|c|}
\hline \multirow[b]{2}{*}{ No } & \multirow[b]{2}{*}{ 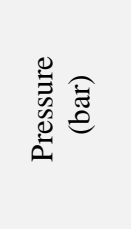 } & \multirow{2}{*}{ 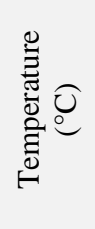 } & \multirow[b]{2}{*}{ 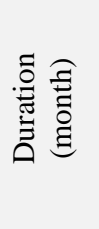 } & \multirow[b]{2}{*}{ 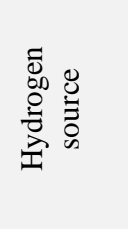 } & \multirow[b]{2}{*}{ 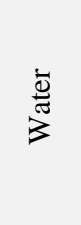 } & \multirow[b]{2}{*}{ 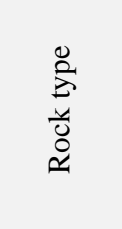 } & \multirow{2}{*}{ 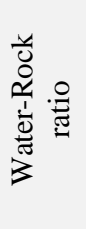 } & \multicolumn{4}{|c|}{ Analytical results } \\
\hline & & & & & & & & 壳 & 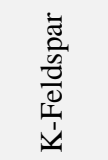 & 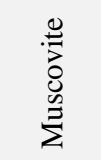 & 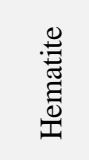 \\
\hline 1 & 100 & 100 & 1,5 & - & - & Powder & 0 & $\mathrm{~T} \mathrm{X}$ & $\mathrm{T} \mathrm{X}$ & $\mathrm{TX}$ & $\mathrm{T} \mathrm{X}$ \\
\hline 2 & 100 & 100 & 1,5 & Pure $\mathrm{H}_{2}$ & - & Powder & 0 & $\mathrm{~T} \mathrm{X}$ & $\mathrm{T} \mathrm{X}$ & $\mathrm{T} \underline{X}$ & $\mathrm{~T} \underline{X}$ \\
\hline 3 & 100 & 200 & 1,5 & Pure $\mathrm{H}_{2}$ & - & Core $^{b}$ & 0 & TX S & TX S & $\mathrm{T} \underline{X} \underline{S}$ & $\mathrm{~T} \underline{\mathrm{X}} \mathrm{S}$ \\
\hline 4 & 100 & 200 & 3 & Pure $\mathrm{H}_{2}$ & - & Powder & 0 & $\mathrm{TX}$ & $\mathrm{T} \mathrm{X}$ & $\mathrm{T} \underline{X}$ & $\mathrm{~T} \underline{X}$ \\
\hline 5 & 100 & 200 & 3 & Pure $\mathrm{H}_{2}$ & - & Core & 0 & TXS & $\mathrm{T} \times \mathrm{S}$ & $\mathrm{T} \underline{X} \underline{S}$ & $\mathrm{~T} \underline{\mathrm{X}} \mathrm{S}$ \\
\hline 6 & 100 & 100 & 6 & Pure $\mathrm{H}_{2}$ & - & Powder & 0 & $\mathrm{TX}$ & $\mathrm{T} \mathrm{X}$ & $\mathrm{T} \underline{X}$ & $\mathrm{~T} \underline{X}$ \\
\hline 7 & 100 & 100 & 6 & Pure $\mathrm{H}_{2}$ & - & Core & 0 & TX S & $\mathrm{TXS}$ & $\mathrm{T} \underline{X} \underline{S}$ & $\mathrm{~T} \underline{\mathrm{X}} \mathrm{S}$ \\
\hline 8 & 10 to 50 & 100 & 1,5 & $\mathrm{H}_{2}{ }^{\mathrm{a}}$ & $\mathrm{H}_{2} \mathrm{O}$ & Core & 0,1 & TX S & TX S & $\mathrm{T} \underline{X} \underline{S}$ & $\mathrm{~T} \underline{\mathrm{X}} \mathrm{S}$ \\
\hline $\begin{array}{l}{ }^{a} \mathrm{Hydr} \\
{ }^{\mathrm{b}} \text { The c } \\
\text { T: tex } \\
\text { X: XR } \\
\text { S: che } \\
\text { Chans }\end{array}$ & $\begin{array}{l}\text { en generate } \\
\text { e was satur } \\
\text { re analysis } \\
\text { analysis } \\
\text { ical analysi }\end{array}$ & $\begin{array}{l}\text { m the } \\
\text { with } v\end{array}$ & $\begin{array}{l}\text { on of } v \\
\text { efore }\end{array}$ & $\begin{array}{l}\text { er and iro } \\
\text { experime }\end{array}$ & 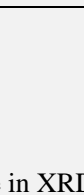 & 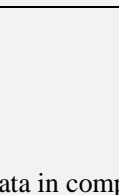 & & 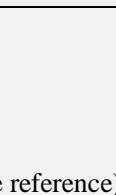 & & & \\
\hline
\end{tabular}




\section{ACCEPTED MANUSCRIPT}

Table 4 Phases present in XRD analysis

\begin{tabular}{|c|c|c|c|c|c|c|}
\hline \multirow{2}{*}{$\begin{array}{l}\text { experiment } \\
\text { number }\end{array}$} & \multicolumn{6}{|c|}{ Phases present } \\
\hline & Quartz & K-feldspar & Muscovite & Hematite & Magnetite & Kaolinite \\
\hline 1 & + & + & + & + & - & - \\
\hline 2 & + & + & + & + & - & - \\
\hline 3 & + & + & + & + & - & $?$ \\
\hline 4 & + & + & + & + & - & - \\
\hline 5 & + & + & + & + & - & - \\
\hline 6 & + & + & + & + & - & - \\
\hline 7 & + & + & + & + & - & - \\
\hline 8 & + & + & + & + & - & - \\
\hline
\end{tabular}


Table 5 Representative electron microprobe analysis of minerals before and after the experiments

\begin{tabular}{|c|c|c|c|c|c|c|c|c|c|c|c|c|c|c|c|}
\hline & \multicolumn{5}{|c|}{ K-feldspar } & \multicolumn{5}{|c|}{ Muscovite } & \multicolumn{5}{|c|}{ Hematite } \\
\hline & $\begin{array}{c}\text { Starting } \\
\text { sandstone }\end{array}$ & Exp. n³ & Exp. n5 & Exp. $n^{\circ} 7$ & Exp. $n^{\circ} 8$ & $\begin{array}{c}\text { Starting } \\
\text { sandstone }\end{array}$ & Exp. nº & Exp. n5 & Exp. ${ }^{\circ} 7$ & Exp. $n^{\circ} 8$ & $\begin{array}{c}\text { Starting } \\
\text { sandstone }\end{array}$ & Exp. $n^{\circ} 3$ & Exp. nº5 & Exp. ${ }^{\circ} 7$ & Exp. $n^{\circ} 8$ \\
\hline $\mathrm{SiO} 2$ & $64.9(3)$ & 64.3 & 65.4 & 64.1 & 64.8 & $47.3(9)$ & $46.7(10)$ & $47.5(98)$ & $46.9(7)$ & $45.8(9)$ & $0.08(2)$ & 0.02 & 0.09 & 0.04 & 0.07 \\
\hline $\mathrm{TiO} 2$ & 0.07 (1) & 0.00 & 0.00 & 0.00 & 0.10 & $0.78(44)$ & $0.61(17)$ & $0.67(25)$ & $0.84(20)$ & $1.06(21)$ & $9.12(34)$ & 10.2 & 10.0 & 9.70 & 9.01 \\
\hline $\mathrm{Al} 2 \mathrm{O} 3$ & $18.1(6)$ & 18.1 & 18.0 & 18.3 & 17.9 & $31.4(5)$ & $34.3(9)$ & 31.9 (9) & $31.3(10)$ & $32.8(2)$ & $0.48(11)$ & 0.00 & 0.00 & 0.52 & 0.30 \\
\hline $\mathrm{FeO}_{\mathrm{t}}$ & $0.00(0)$ & 0.11 & 0.10 & 0.17 & 0.10 & $3.54(44)$ & $1.34(58)$ & $2.14(45)$ & $2.48(38)$ & $1.24(14)$ & $85.2(5)$ & 87.4 & 86.3 & 84.1 & 85.3 \\
\hline $\mathrm{MnO}$ & $0.00(1)$ & 0.00 & 0.13 & 0.00 & 0.00 & $0.03(5)$ & $0.06(6)$ & $0.03(4)$ & $0.05(6)$ & $0.04(3)$ & $0.22(27)$ & 0.16 & 0.38 & 0.50 & 0.63 \\
\hline $\mathrm{MgO}$ & $0.00(0)$ & 0.00 & 0.01 & 0.03 & 0.00 & $1.20(1)$ & $0.74(19)$ & $1.21(31)$ & $0.65(48)$ & $0.82(10)$ & $0.02(5)$ & 0.50 & 0,00 & 0,00 & 0.02 \\
\hline $\mathrm{CaO}$ & $0.00(0)$ & 0.01 & 0.00 & 0.00 & 0.01 & $0.00(0)$ & $0.03(2)$ & $0.03(4)$ & $0.00(0)$ & $0.00(1)$ & $0.03(1)$ & 0.00 & 0.00 & 0.00 & 0.03 \\
\hline $\mathrm{Na} 2 \mathrm{O}$ & $0.37(26)$ & 0.21 & 1.38 & 0.62 & 0.15 & $0.44(9)$ & $0.41(15)$ & $0.33(15)$ & $0.39(12)$ & $0.59(5)$ & $0.01(1)$ & 0.00 & 0.00 & 0.00 & 0.00 \\
\hline $\mathrm{K} 2 \mathrm{O}$ & $16.1(7)$ & 16.5 & 14.5 & 15.6 & 16.2 & $10.2(2)$ & $10.5(2)$ & $10.2(3)$ & $9.86(26)$ & $9.12(24)$ & $0.03(2)$ & 0.05 & 0.03 & 0.01 & 0.00 \\
\hline Total & $99.6(2)$ & 99.2 & 99.6 & 98.9 & 99.3 & $94.8(10)$ & $94.3(10)$ & $94.1(1)$ & $95.5(2)$ & $91.5(9)$ & $95.2(9)$ & 98.3 & 96.9 & 94.9 & 95.4 \\
\hline
\end{tabular}


Table 6 Stable and product minerals and saturation indices (SI) predicted to the be present at equilibrium from PHREEQC calculations

\begin{tabular}{ccc}
\hline Stable minerals & Product minerals & Saturation indexes \\
\hline Quartz & - & 0.00 \\
K-feldspar & Magnetite & 0.00 \\
& Annite & 3.01 \\
& Chamosite & 9.43 \\
Cronstedtite & 3.85 \\
& Fayalite & 5.63 \\
Wustite & 3.98 \\
& Ferrosilite & 0.49 \\
Greenalite & 2.03 \\
& Minesotaite & 8.31 \\
& Nontronite & 9.23 \\
\hline
\end{tabular}




\section{ACCEPTED MANUSCRIPT}

Table A1 List of kinetic rate parameters

\begin{tabular}{|c|c|c|c|c|c|c|c|c|c|c|}
\hline \multirow{3}{*}{$\begin{array}{l}\text { Primary } \\
\text { minerals }\end{array}$} & \multirow{3}{*}{$\begin{array}{c}\text { Volume } \\
\text { fraction } \\
\%\end{array}$} & \multirow{3}{*}{$\begin{array}{c}\text { Specific } \\
\text { surface area, } \\
\text { A }\left(\mathrm{cm}^{2} / \mathrm{g}\right)\end{array}$} & \multicolumn{8}{|c|}{ Kinetic rate parameters } \\
\hline & & & \multicolumn{2}{|c|}{ Neutral mechanism } & \multicolumn{3}{|c|}{ Acid mechanism } & \multicolumn{3}{|c|}{ Base mechanism } \\
\hline & & & $\begin{array}{c}\mathrm{k}_{25} \\
\left(\mathrm{~mol} / \mathrm{m}^{2} \mathrm{~s}\right)\end{array}$ & $\begin{array}{c}\mathrm{E}_{\mathrm{a}} \\
(\mathrm{kJ} / \mathrm{mol})\end{array}$ & $\mathrm{k}_{25}$ & $\mathrm{E}_{\mathrm{a}}$ & $\mathrm{n}\left(\mathrm{H}^{+}\right)$ & $\mathrm{k}_{25}$ & $\mathrm{E}_{\mathrm{a}}$ & $\mathrm{n}\left(\mathrm{H}^{+}\right)$ \\
\hline Quartz & 74 & 10 & $10.2 \times 10^{-14}$ & 87.7 & & & & & & \\
\hline K-feldspar & 22 & 10 & $3.89 \times 10^{-13}$ & 38.0 & $8.71 \times 10^{-11}$ & 51.7 & 0.5 & $6.31 \times 10^{-22}$ & 94.1 & -0.823 \\
\hline Muscovite & 2 & 20 & $1.00 \times 10^{-13}$ & 22.0 & & & & & & \\
\hline Hematite & 1 & 20 & $2.51 \times 10^{-15}$ & 66.2 & $4.07 \times 10^{-10}$ & 66.2 & 1.0 & & & \\
\hline
\end{tabular}

Kinetic rate constants of all the mechanisms are given at $25^{\circ} \mathrm{C}$. These kinetic parameters were taken from the scientific literature, mostly from Palandri and Kharaka (2004). 


\section{FIGURE CAPTIONS}

Figure 1. Configurations of experimental charges used in this study. (a) experiments performed under pure $\mathrm{H}_{2}$ gas. The sandstone sample (either core or powder) is loaded in a Au capsule fitted with porous ceramic plugs at both ends, allowing $\mathrm{H}_{2}$ to freely access to the sample. (b) experiment performed with a $\mathrm{H}_{2} \mathrm{O}-\mathrm{H}_{2}$ gas mixture. The sample is loaded together with $\mathrm{Fe}$ powder and $\mathrm{H}_{2} \mathrm{O}$ in a Au capsule that is hermetically closed by welding. Experimental charges such as in (a) or (b) are then placed in an horizontal pressure vessel. See text for additional details.

Figure 2. SEM photomicrographs of starting materials and experimental products. (a), (b), (c), photomicrographs of the main mineral phases in the starting sandstone, quartz (Qtz, a), K-feldspar $(\mathrm{Kfs}, \mathrm{a})$, muscovite $(\mathrm{Mu}, \mathrm{b})$ and hematite $(\mathrm{FeOx}, \mathrm{c})$. (d), (e), (f), photomicrographs of representative products from the "dry" experiments (performed with pure $\mathrm{H}_{2}$ gas) showing quartz and K-feldspar (d), muscovite (e) and hematite (f). Same abbreviations as in (a), (b) and (c). (g), (h), (i), photomicrographs of products from the "wet" experiment (performed with a $\mathrm{H}_{2} \mathrm{O}-\mathrm{H}_{2}$ gas mixture) showing quartz and K-feldspar (g), muscovite (h) and hematite (i). Same abbreviations as in (a), (b) and (c). See text for explanations.

Figure 3. Evolution of XRD peaks of muscovite at $2 \Theta=10.315^{\circ}, 20.737^{\circ}, 23.087^{\circ}, 47.796^{\circ}$ in experimental products (exp. $\left.\mathrm{n}^{\circ} 2,4,6,8\right)$ and in the reference $\left(\exp . \mathrm{n}^{\circ} 1\right)$. See Table 3 for experimental conditions and text for explanations.

Figure 4. Evolution of XRD peaks of hematite at $2 \Theta=38.694^{\circ}, 41.599^{\circ}, 58.153^{\circ}, 63.741796^{\circ}$, $74.024^{\circ}$ in experimental products (exp. $\left.\mathrm{n}^{\circ} 2,3,4,5,6,7,8\right)$ and in the reference (exp. $\left.n^{\circ} 1\right)$. See Table 3 for experimental conditions and text for explanations.

Figure 5. Geochemical modeling of simple sandstone mineral dissolution in a $\mathrm{H}_{2} \mathrm{O}-\mathrm{H}_{2}$ fluid using PHREEQC. Mass fractions of mineral phases (normalized to $100 \mathrm{~g}$ of sandstone) are plotted as a function of time for timescales ranging from $10^{-6}$ to $10^{2}$ years. (a) evolution of the quartz mass fraction; (b) evolution of the K-feldspar mass fraction; (c) evolution of the muscovite mass fraction; (d) evolution of the hematite mass fraction. For each panel, results are shown for the 3 water/rock ratios (W/R) considered. The vertical dashed line gives the maximum duration of the experiments (Table 3). See text for details about the calculations.

Figure 6. Geochemical modeling of coupled hematite dissolution and magnetite precipitation in a $\mathrm{H}_{2} \mathrm{O}-\mathrm{H}_{2}$ fluid using PHREEQC. Each panel is for a given W/R ratio, from 0.1 (a), 1 (b) to 10 (c). On each panel, the evolution of the mass fraction of hematite during dissolution in the fluid (left axis, normalized to $100 \mathrm{~g}$ of reacted sandstone) is plotted as a function of time for timescales ranging from $10^{-6}$ to $10^{2}$ years. Dissolution curves for hematite with and without magnetite precipitation (simple dissolution, as in Figure 5) are compared to demonstrate the influence of magnetite on hematite dissolution. The curve describing the mass of produced magnetite is shown with the scale on the right axis (normalized to $100 \mathrm{~g}$ of reacted sandstone). The vertical dashed line gives the maximum duration of the experiments (Table 3). See text for details about the calculations.

Figure 7. Geochemical modeling of coupled mineral dissolution and precipitation in a $\mathrm{H}_{2} \mathrm{O}-\mathrm{H}_{2}$ fluid using PHREEQC. Product phases considered in the calculations include magnetite, annite and chamosite. W/R is fixed to 1 in both panels. (a) evolution of the mass fraction of quartz and Kfeldspar during dissolution in the fluid with and without product phases included. Mass fractions of quartz and K-feldspar (left axis, normalized to $100 \mathrm{~g}$ of reacted sandstone) are plotted as a function of time for timescales ranging from $10^{-6}$ to $10^{2}$ years. (b) evolution of the mass fraction of hematite during dissolution in the fluid with and without product phases. The mass fraction of hematite (left axis, normalized to $100 \mathrm{~g}$ of reacted sandstone) is plotted as a function of time for timescales ranging from $10^{-6}$ to $10^{2}$ years. The curves describing the mass of product phases (only annite and chamosite, magnetite never appears as a product phase when annite is allowed to be present) are shown with the scale on the right axis (normalized to $100 \mathrm{~g}$ of reacted sandstone). The vertical 
dashed line gives the maximum duration of the experiments (Table 3). See text for details about the calculations.

Figure 1.

(a)

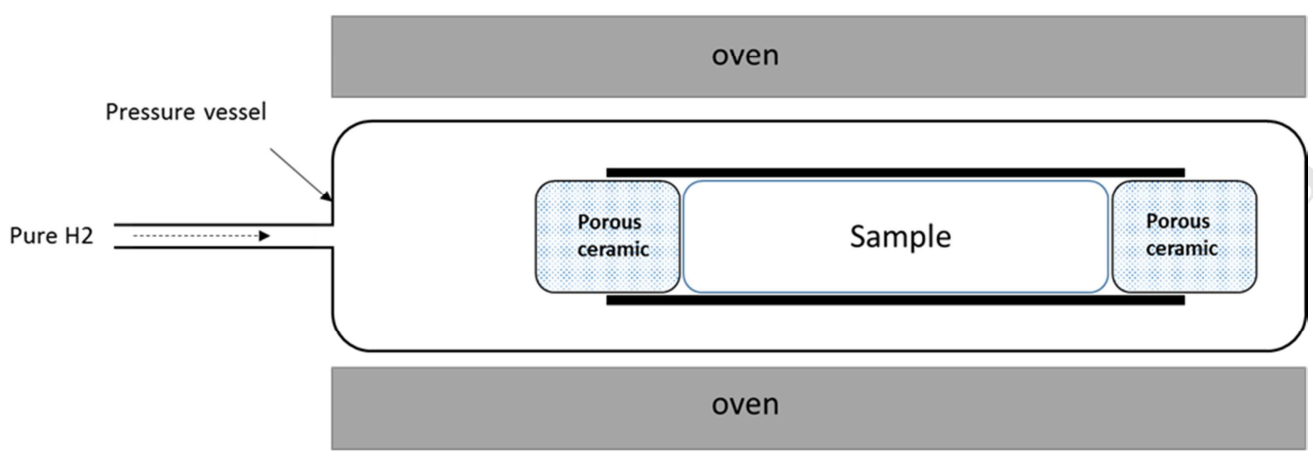

- Capsule open at both ends

(b)

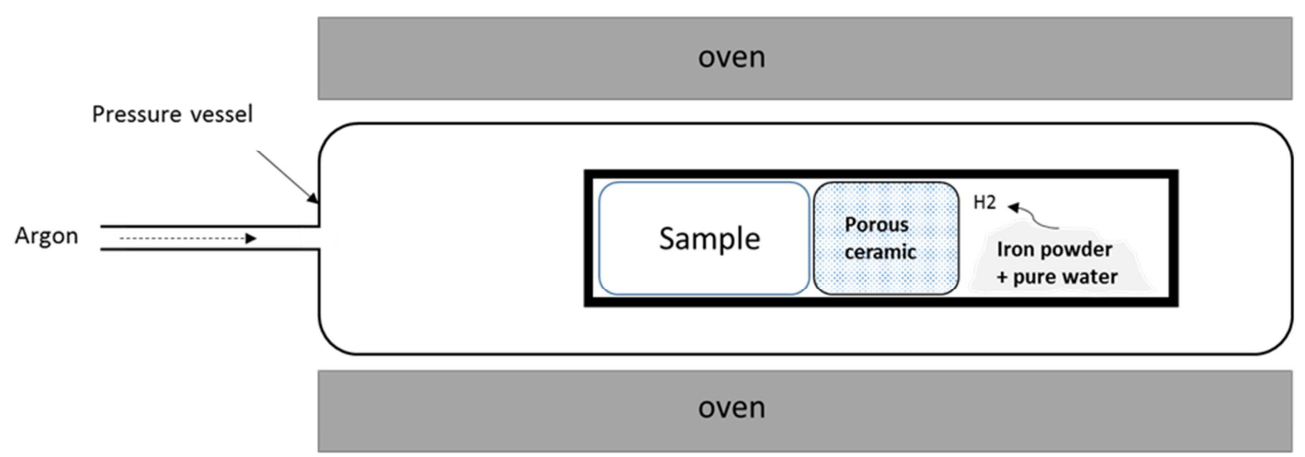

Capsule hermetically closed 


\section{ACCEPTED MANUSCRIPT}

Figure 2.

Before experiments

After experiments
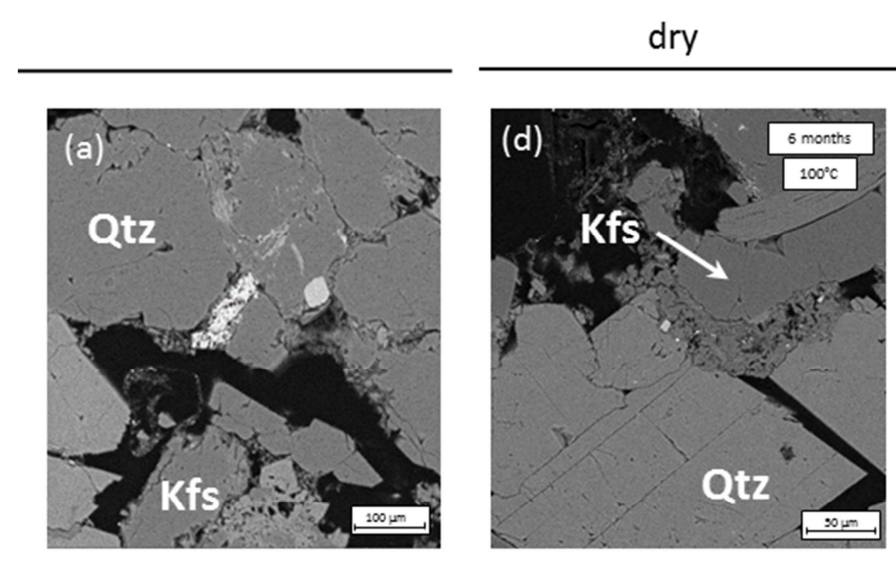

wet
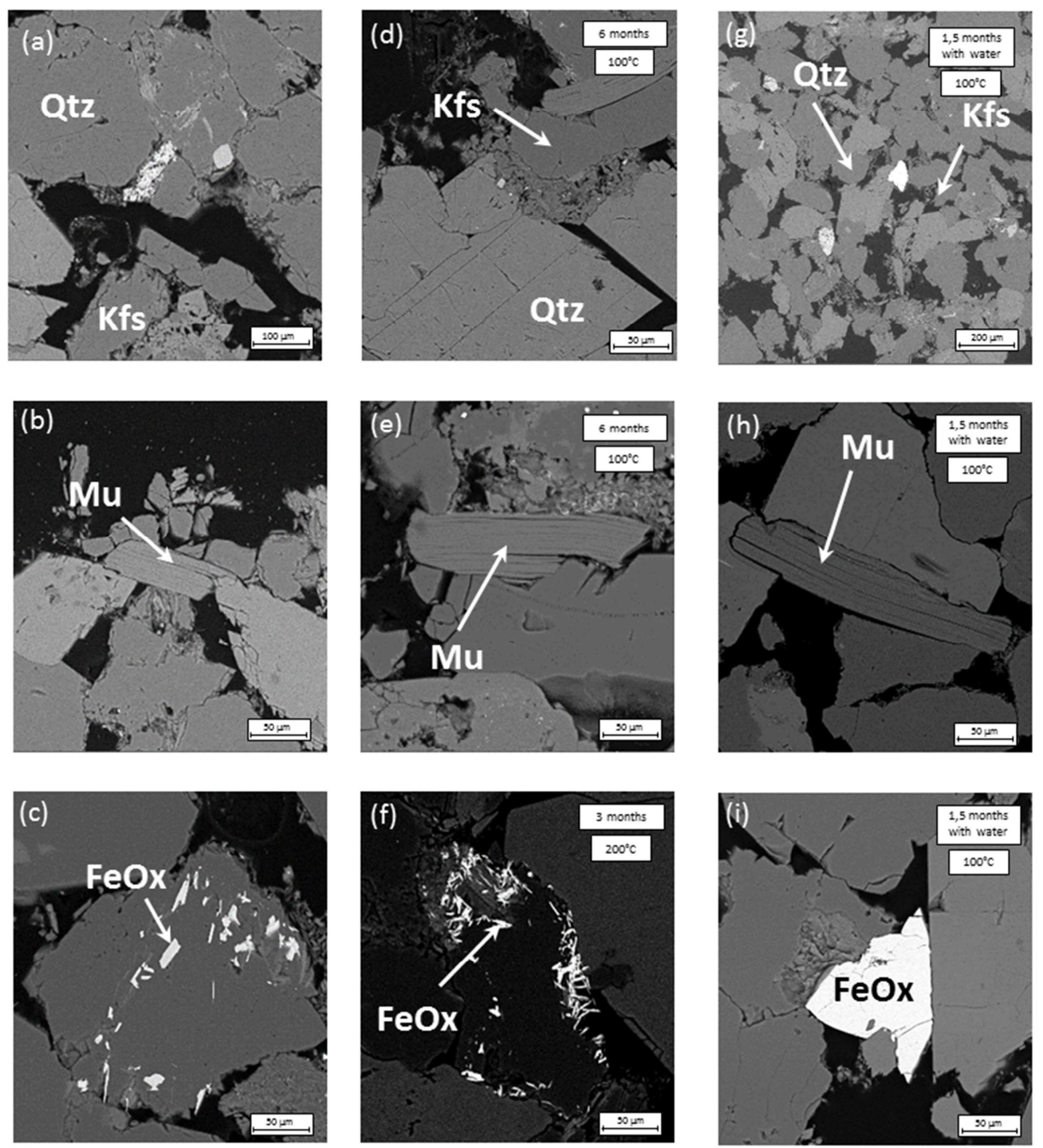
Figure 3.

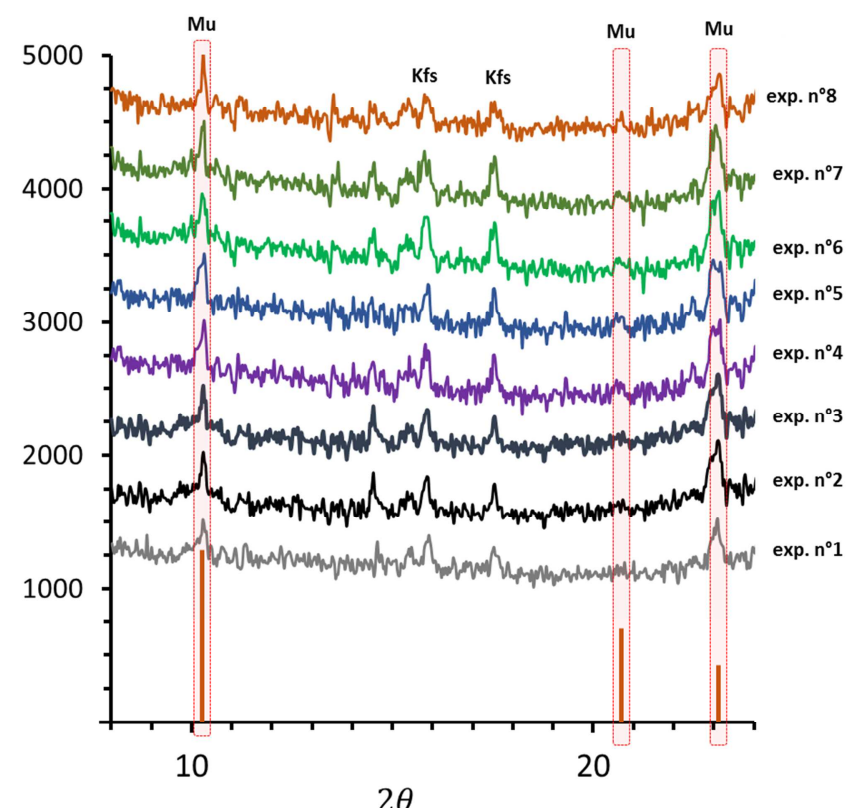

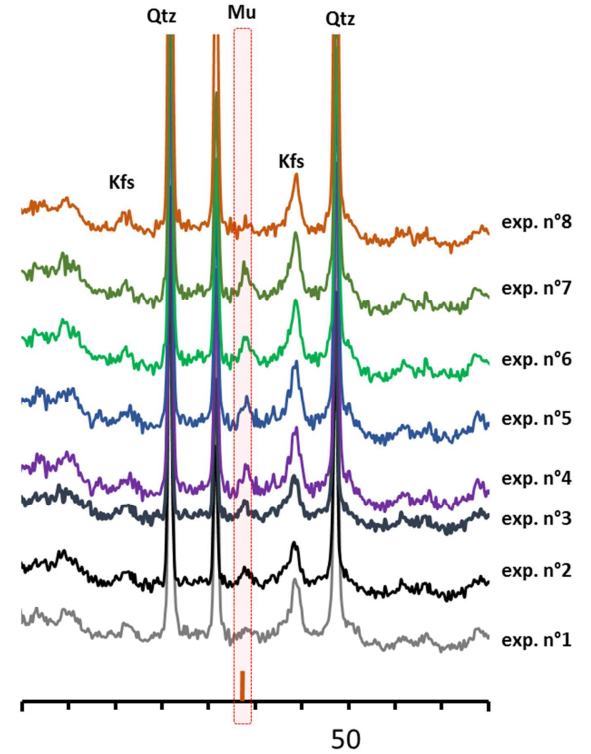

$2 \theta$ 
Figure 4.

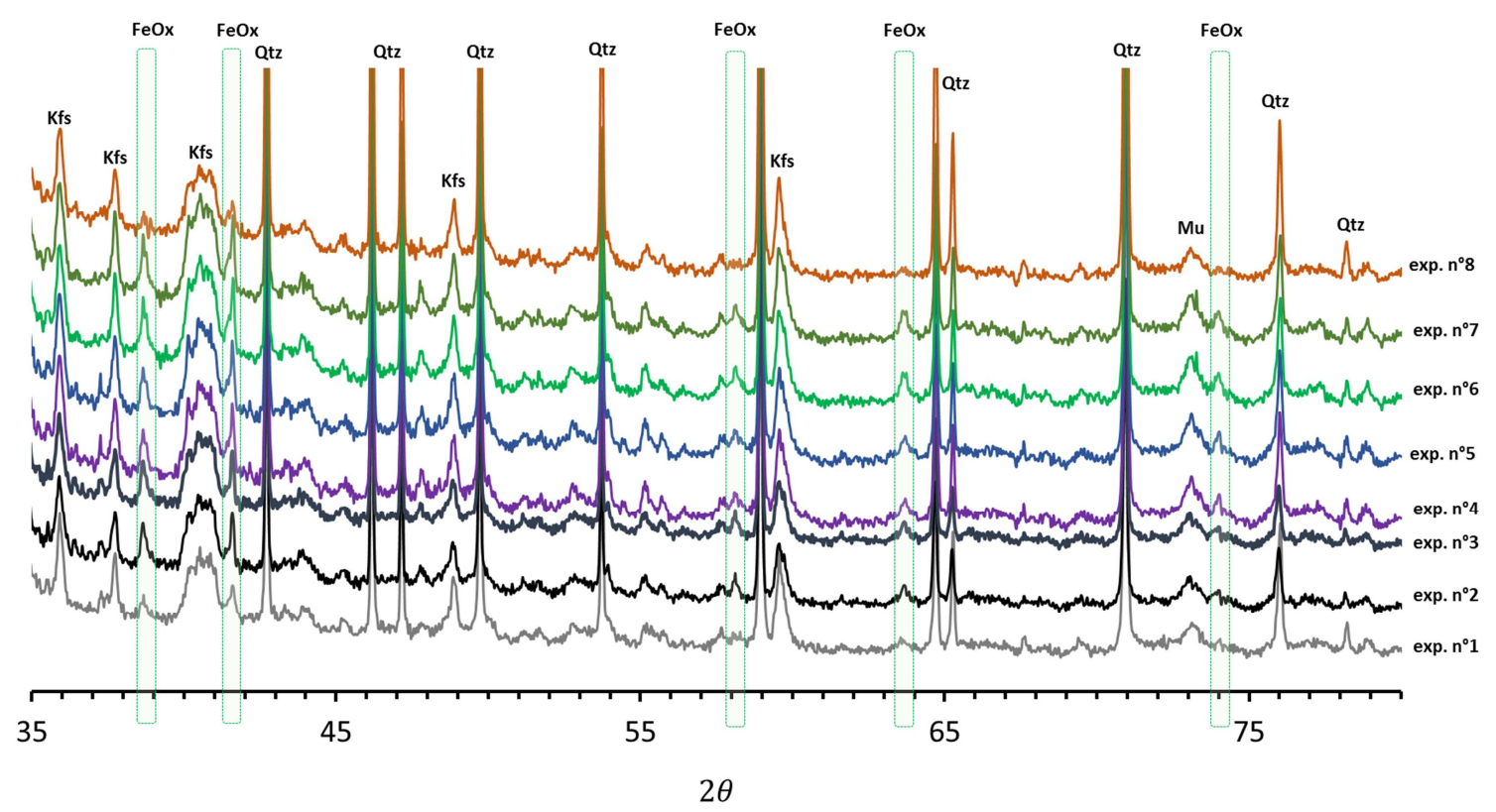


Figure 5.
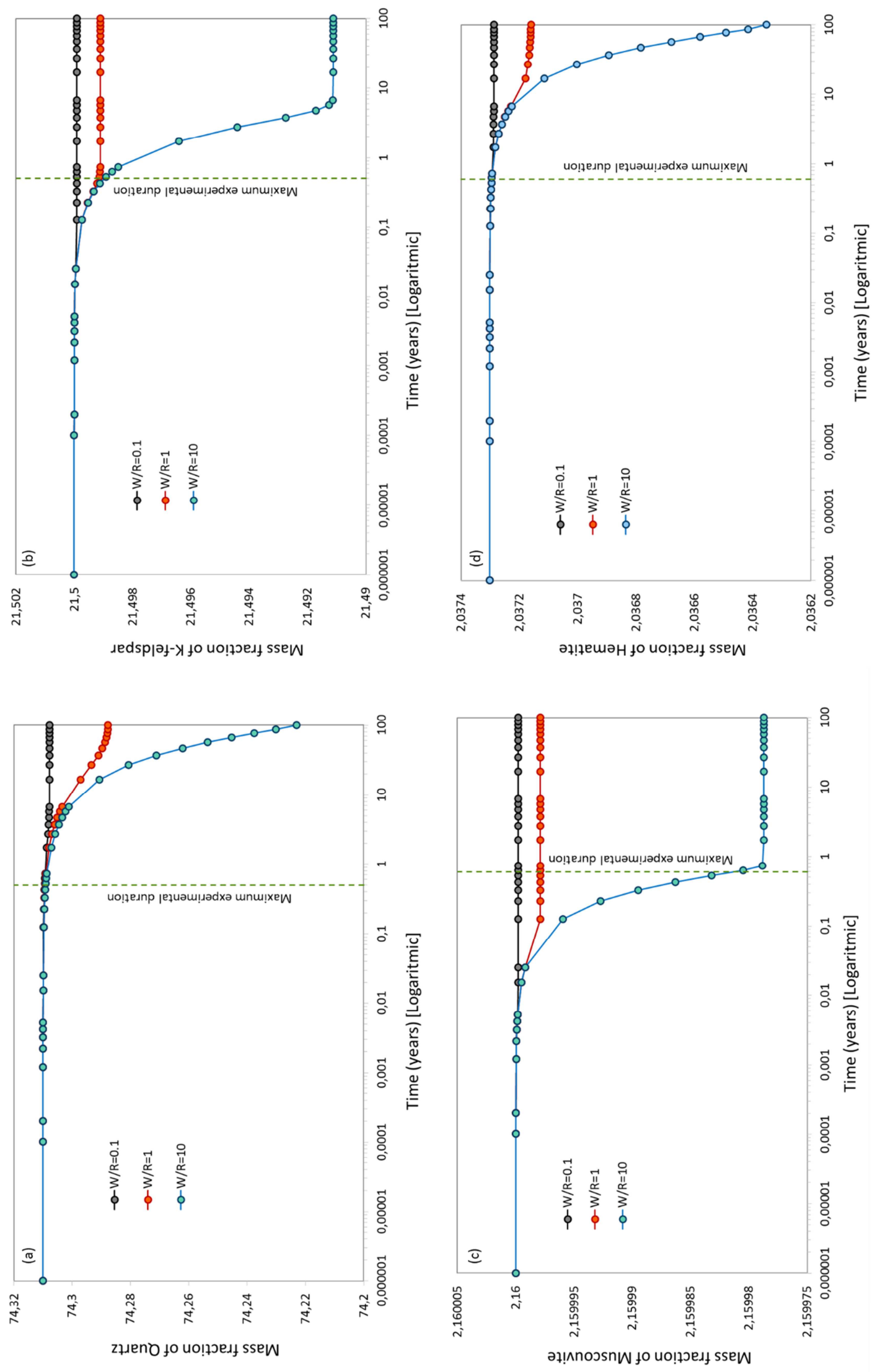
Figure 6.

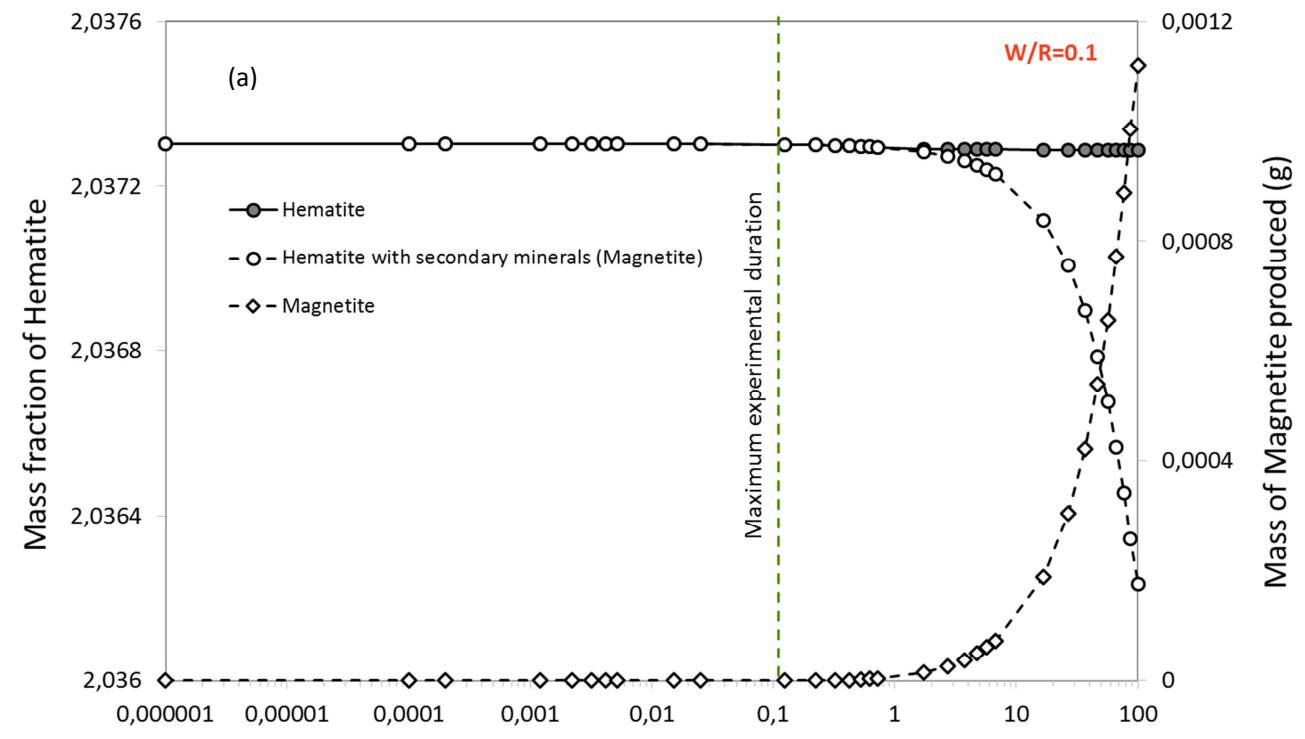

Time (years) [Logaritmic]

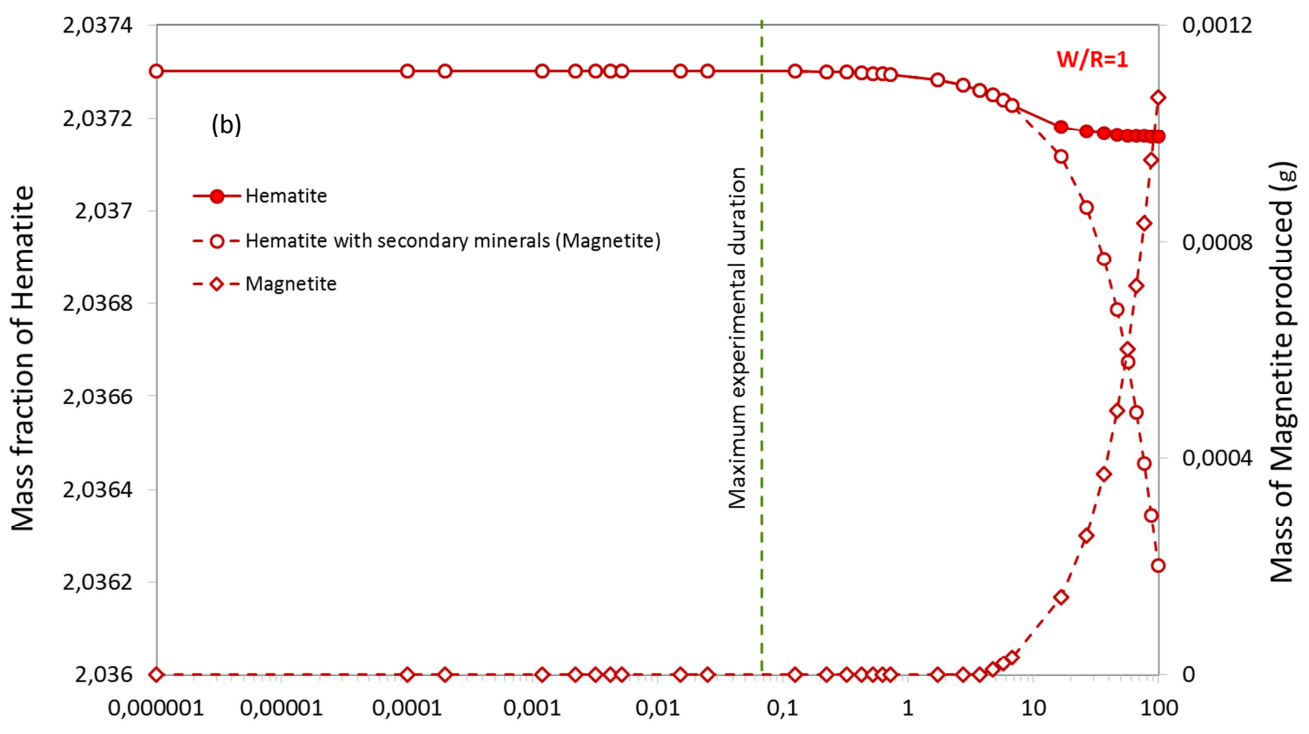

Time (years) [Logaritmic]

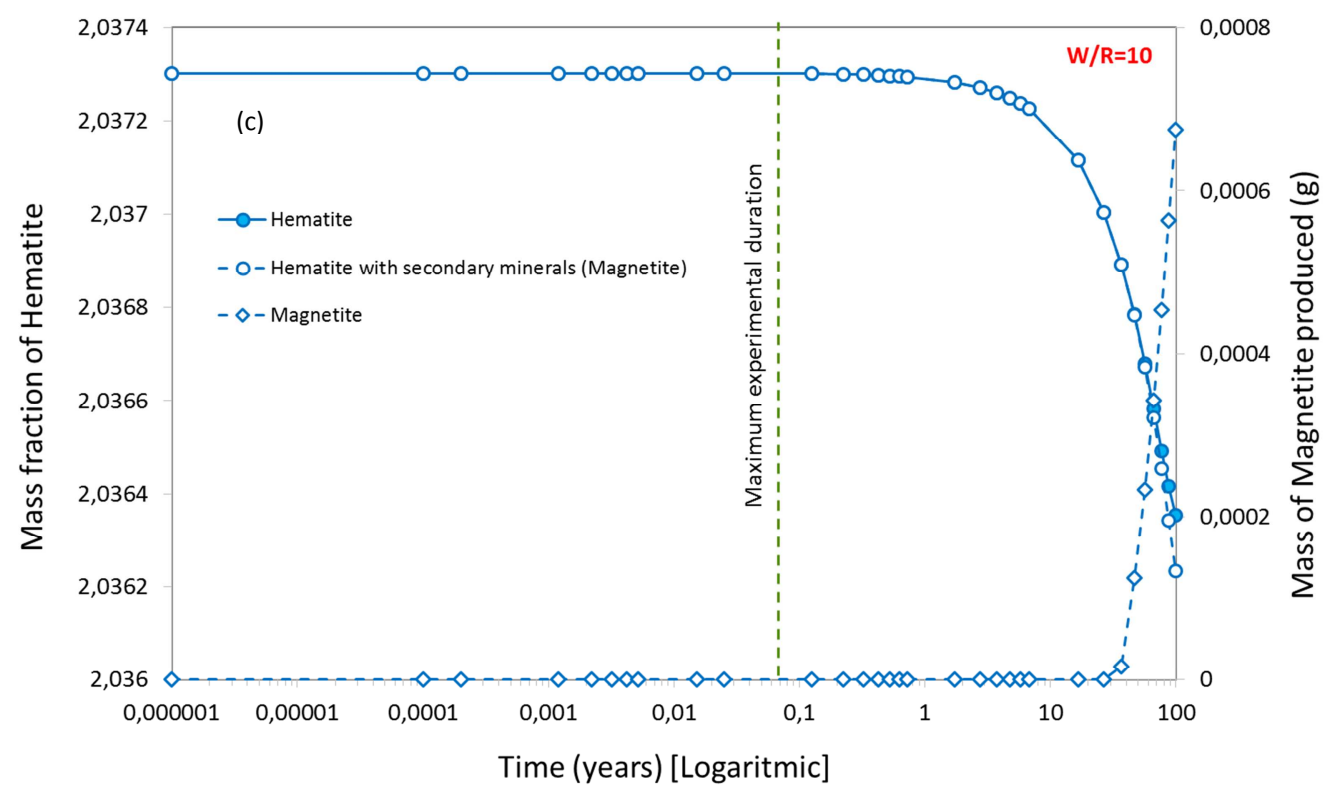


Figure 7.
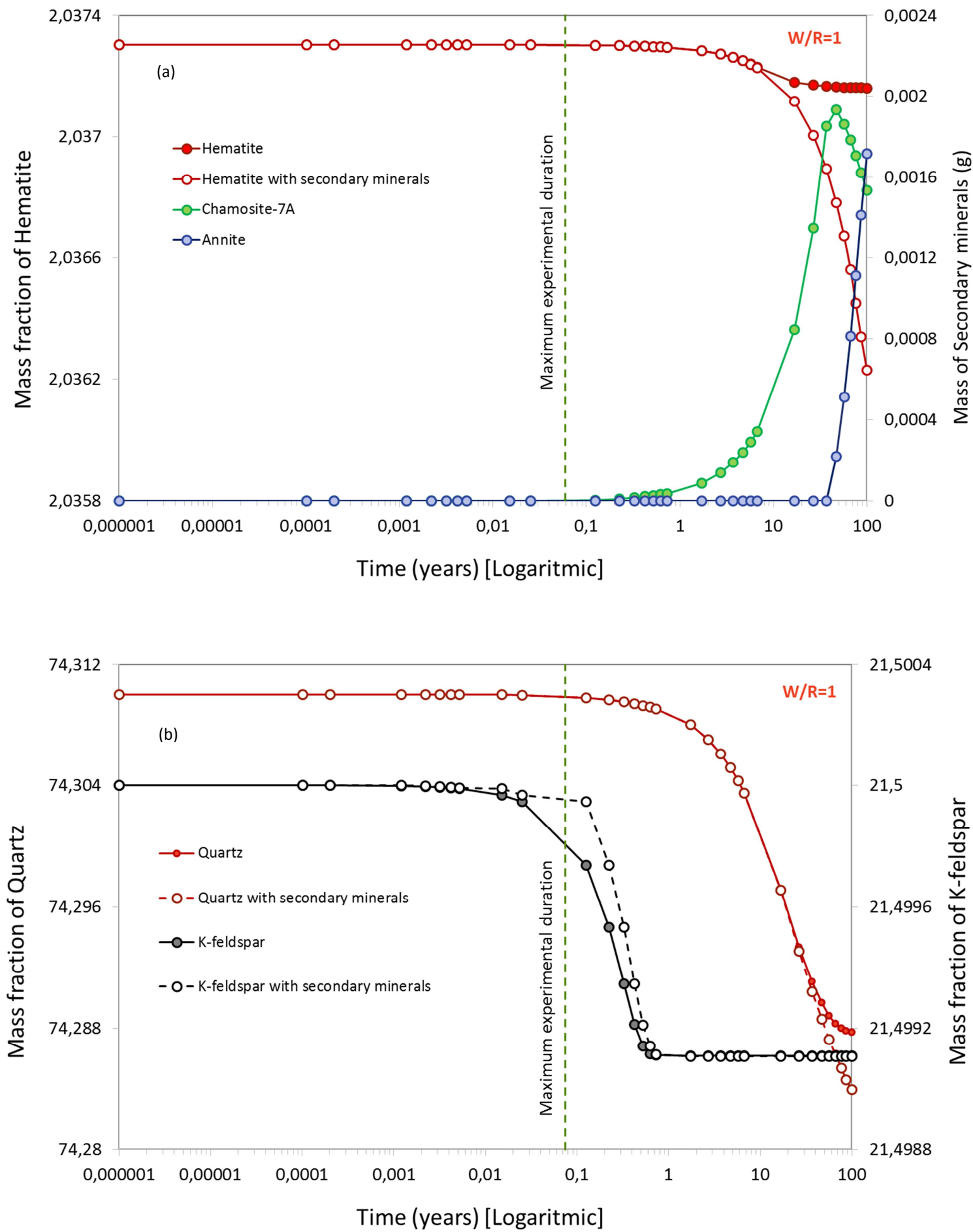
- In this study, the interaction of hydrogen with rock minerals were studied

- Minor modifications of sandstone mineralogy identified in experimental results because of the presence of hydrogen

- The experimental results undoubtedly indicate that mineral reactions take place in sandstone during interaction with hydrogen

- Numerical results indicated little effect on the dissolution of minerals except Hematite due to presence of hydrogen

- Microstructure and Rock physical properties unmodified, due to sandstone major mineral phases (Quartz, K-feldspar) unaffected in contact with hydrogen 